\title{
Discovering bog bodies
}

\section{Introduction}

They lay in the peat moss 28 years and 9 months before they were looked at again, when some Countrymen, having observed, I suppose, the extraordinary Quality of this Soil, in preserving dead bodies from corrupting, were curious enough to open the ground to see if these Persons had been so preserved, and found them in no way altered, the Colour of their Skin being fair and natural, their Flesh soft as that of Persons newly dead. (Part of a letter from Dr Charles Balguy of Peterborough, to Cromwell Mortimer, MD, cited in Balguy 1735: 413)

This correspondence between two men of science alludes to the bog bodies that have become known (somewhat ironically) as the 'Hope couple' (van der Sanden 1996: 19). While a historic case, whose tragic end on the upland peat bog of Hope Woodland was well documented by the local vicar, Wormald, this telling line in Balguy's letter alludes to a phenomenon of peat preservation that was apparently well known by the locals. Balguy had grown up in the parish of Hope; his forebears were 'Overseers of the Poor' and their signatures litter the accounts of small payments to widows and orphans or countersign canny expulsions of unmarried mothers crossing to 'the other side' of a parish boundary to defray any ongoing financial responsibility towards these poor women. He himself took a medical path, which perhaps explains his curiosity about the local couple who died in a snowstorm and were buried where they fell.

The background to these events is intriguing. On 14 January 1674, a man named Barber - a 'considerable Grazier ... well-known by the People that found him ... [but] reduced in Circumstances', as Balguy (1735: 413) puts it - set off for Ireland with his maidservant. Whether Barber was married or not, or whether this was an elopement due to their servant and master relationship, is unclear. The route they took was precarious: marked for the first half only by prehistoric cairns, sheep walks and perhaps a packhorse track, but lacking many of the stone-built enclosure walls and formal paths visible on the later first edition Ordnance Survey 
map. It is thought that they were trying to cross Whin Hill: the sharp eminence that overshadowed their valley. Perhaps it was the most visible landmark on a dark day, but before them lay the upland bog that skirted this peak. They did not make it. Intimate details are revealed in Balguy's account, gleaned from his close colleague Dr Bourn of Chesterfield, who saw the remains in 1716 and recalled that the woman was dressed 'in new serge' while the man had on 'a Broad-cloth coat, which he had tried to tear a skirt off, but could not' (Balguy 1735: 414). The detail of this well-preserved clothing, which had nonetheless failed to protect them from the engulfing snow, is both moving and appalling. They were not found until May of that year, with 'Snow lasting probably the greatest part of the Time' (Balguy 1735: 413), by which point the smell of the decaying bodies prompted the coroner to recommend that they be buried on the spot (Cox 1877). Yet there was another reason to bury them there: dying in a non-ecclesiastical parish, without so much as a chapel nearby, absolved anyone of the responsibility - or cost - of formal burial. The 'whiff of scandal' that Briggs and Turner (1986: 183) detect in this case might also explain their abandonment to the peat. It was only forty-eight years later, as we shall see, that they were accorded Christian interment: Barber's grandson being 'at the Expense of a decent Funeral for them' (Balguy 1735: 414).

Balguy's letter was motivated by his scientific interest in the phenomenon of the bog body, eager to communicate this to the wider audience of the Royal Society, following a number of letters and reports about such remains (e.g. King 1685; Leigh 1700). Yet his view is poised on the cusp of conflicting interpretations about these bodies, and how their remarkable preservation was understood by contemporary society. This chapter concerns the discovery of such remains what people felt and why they were sometimes motivated, like the locals of Hope valley, to seek them out. The chapter traces transformations in attitudes towards bodies from the bog, from the earliest archival records to the recent past: examining how these bodies were reported and to whom, how the condition of such corpses was understood and how this shaped the fate of their remains. It charts the move from late medieval supernatural awe and folkloric fear to antiquarian curiosity; historic tensions in religious beliefs about the dead and their afterlives during the Reformation and its aftermath, to the rise of Enlightenment paradigms that sought to explain through science rather than to sacralise. It then turns to the claims laid upon these remains as they became evidence in nineteenth-century nationalist narratives: examining the role bog bodies played in racial and then ethnic debates over the long-term past of a people. Finally, it shows how their lives and deaths are now firmly shaped by forensic discourse. Throughout, the chapter argues that despite their marvellous preservation, the dead will not simply 'speak' to us; their stories are filtered through beliefs of the day, which determined whether they were reburied, kept or curated. This historiographic approach also reveals the poetics of encounter, helping us to understand the shifting, peculiar power of these remains. 


\section{'Such a cry about a corpse'... stories of the marvellous dead}

The poem of St Erkenwald was composed around AD 1400, and judging by its dialect, it was written by a native of Cheshire or someone living close to the north border of Wales, around the time of the Glyndwr rebellion (Anon. 1977). Its central concern was an understanding of the turbulence through which English Christianity had emerged, providing cautionary context to the later medieval rebellion that was unfolding around the author. But what interests us here is an overlooked passage concerning well-preserved remains. Like the disruptive effect of the body revealed in the poem, its opening lines disorientate the reader in time and disabuse them of any simple, linear history (Schwyzer 2006: 4). Set in the Anglo-Saxon period, lines 43-158 tell of the destruction of a pagan shrine by Erkenwald's congregation, in order to raise the 'New Werke' of what would become St Paul's Cathedral. But as the workmen 'dyght and delve so depe into the earth / They founden formyt on a flore a fery faire tombe' ('dug and delved so deep into the earth / they found formed on a floor a wonderfully fair tomb') (Anon. 1977: lines 45-46). The description of the interment, with its gold-inscribed lettering and stone sarcophagus, sounds more Roman than Iron Age, as does the description of the 'a blissfull body', a 'marvel' resplendent with gold-hemmed raiment, crown and sceptre, but it is the state of the body and its clothes that attracts the poet's main attention:

His clothes were spotless, without any sign of being mouldered, spotted or motheaten, and were as brightly coloured with glistening hues, as if they had been woven yesterday in that churchyard. Likewise his face was fresh, and the visible flesh of his ears and hands was fresh and ruddy as the rose, with two red lips, as if he in full health had slipped suddenly into sleep. (Anon. 1977: lines 85-92)

As Schwyzer (2006: 6) goes on to explain, any later medieval reader of this stanza would have immediately connected this discovery to the miraculously preserved bodies found in other Christian settings, such as Joan of Acre from Clare Priory in Suffolk or the iconic remains of St Cuthbert that formed the centrepiece of pilgrimage at Durham Cathedral (O'Brien 2016). As Bede himself put it, 'opening the tomb, [they] found his body entire, as if he were still alive, and his joints flexible, as if he were not dead but sleeping. His clothes also, were still undecayed, and seem to retain their original freshness and colour' (Giles 1863: 343). Likewise, the tenth century account of the Passio Sancti Edmundi by Abbo of Fleury made much of the fact that despite a violent decapitation, repeated exhumations and inspections of both the body and head of St Edmund found them to be miraculously rejoined: the cut represented only by a thin red line, arrow wounds marvellously healed and the body immaculately preserved, attributed by Abbo to his chaste life and martyrdom (van der Sanden 1996: 65). For medieval audiences, incorruptibility was part of the means through which saintliness was evidenced. Yet the poet of St Erkenwald imaginatively conjures instead the shock of the Saxons, who do not yet conceptualise corporeal preservation as a miracle. Tellingly, Schwyzer 
(2006: 7) uses the example of Iron Age bog bodies at this point in his study to evoke the rupturing effect of such a discovery, and likens Erkenwald's disconcerted flock to those of British Museum visitors, gathered around Lindow Man - ironically (given the original authorial locus of the poem), one of Cheshire's own prehistoric 'bog bodies'.

In the poem, the discovery causes 'suche a cry aboute a cors / crakit evermore' ('such a cry about a corpse / sounding constantly') (line 110) that Bishop Erkenwald himself is called to intervene. He confronts the remains and bids them (in Christ's name) to talk. The figure is momentarily animated by 'sum lant ghostlyfe' ('some borrowed ghost-life') revealing himself to be no king, knight nor Caesar but a judge from the time of Belinius, in 'New Troie' (London), c.382 BC (king, city and date borrowed from Geoffrey of Monmouth's hagiography, 1966). Thus the poem presents us with an apparently well-preserved Iron Age body discovered under the very foundations of St Paul's. This is unlikely to be true - while there are isolated pockets of peat recorded on the south side of the river, the subsurface geology recorded in borehole data for St Paul's consists of sands and silts overlying the blue clays of the Langley Silt Member (British Geological Survey 2019). This could not have been a traditional 'peat' preserved bog body, or at least not from this exact locale.

Unlike his congregation, Erkenwald is not perturbed by its appearance, musing that 'Thi body may be embawmyd / hit bashis me nought' ('thy body may be embalmed / it does not disconcert me') (Anon. 1977: line 261). Yet the corpse replies his preservation is not by human hand but by God himself, by virtue of a life lived in exemplary service of his people: his combined 'meekness and manliness. However, while his body was bestowed with incorruptibility, he groans wearily that his soul is in limbo, being pagan and thus ignorant of 'Thee and thy laws' - in other words, God and his covenant with humanity. At this story, the bishop is moved to tears, and one drop falls on the body, performing a remarkable post-mortem baptism that releases the soul from purgatory into heaven. The act itself becomes of one the miracles that ensure Erkenwald's own sainthood, but there then follows a remarkable alliterative account of rapid putrefaction that suggests first-hand witness of the opening of a well-sealed tomb:

Whyt this cessyd his owne, sayd he no more.

Bot sodenly his swete chere swyndid and faylid

And all the blee of his body wos blakke as the moldes

As roten as the rottek that rises in powdere.

For as sone as the soule was sesyd in blisse,

Corrupt was that of thir crafte that coverte the bones.

(With this his voice ceased and he said no more.

But suddenly his sweet expression faded and failed

And all the colour of his body was as black as mould

As rotten as the decayed matter that rises in powder.

For as soon as the soul was possessed of bliss,

the material that covered the bones decomposed.) (Anon. 1977: lines 341-6) 
What intrigues us here is not the veracity of the incident nor the theological debate that the poem posed to medieval and later scholars, but how the discovery of an incorruptible body was not just received in medieval times but used. Schwyzer (2006: 15) sees the Iron Age judge as an example of quasi-inventiones - an act of revelation used in this passage not to give veracity to a medieval relic (as was normally the case), but to 'confront the enduring presence of the old possessors just beneath the shallow surface of English life': a kind of 'colonial archaeology' designed to give respect and reverence to virtuous pagans even as the act of exhumation consigned them to dust. It is a quite brilliant insight, germane to the making not just of written history but 'of homeland' as Schwyzer (2006) puts it: a power exuded by our very real 'bog bodies', to which I will return later.

This is not the only medieval story of a well-preserved corpse underlying a Christian site. A folkloric tale from Clonmacnoise, Co. Offaly, tells of how the monks here initially refused to believe a local poet's tale that a great warrior was buried in the midst of this early foundation (Carey 1999). During the digging of a grave however, the well-preserved body of a 'yellow-haired giant' emerged, marred by a head wound and covered in blood and birch leaves. Yet the following day the corpse had disappeared. Carey (1999: 13) considers whether this was either a forerunner for the 'Arthurian' burial myth later associated with Glastonbury, or the effect of monastic readings of classical texts pertaining to barbarian bodies interred in the bog. Either way, the parallels with the St Erkenwald tale and the haunting presence of an earlier, pre-Christian inhabitant of a sacred place are rather uncanny.

Why do these earliest accounts of well-preserved bodies matter? All of our written accounts of bog bodies (from Britain and Ireland to Denmark, Germany and Sweden) are viewed through the lens of Christian eschatology: Catholic, Protestant and non-Conformist, until the early twentieth century. To understand what their discovery meant requires us to understand how a preserved corpse was perceived within these faiths, and yet it is here we find the conundrum embodied in the St Erkenwald poem. Not all well-preserved bodies were 'marvels'. Despite the common perception of a perfect corpse as a sign of sainthood (such as Bede's account of Etheldreda, whose flesh 'could not suffer corruption' having never been defiled by man, see Giles 1863: ch. XIX), other narratives such as The Golden Legend instead present us with troubled bodies, as in the monk who had renounced his vows and was thus 'rejected by the earth' (Schwyzer 2006: 10). These latter incorruptibles were plagued not by piety but unfinished pursuits: whether sacred (needing to redeem themselves through consecration or blessing) or secular (fulfilling a debt or righting a wrong). Such individuals may have received the normal Christian rites of burial but their post-mortem behaviour was a sign that something was amiss. Their state need not necessarily mimic the corporeal perfection of the Iron Age magistrate: swollen putrescence was particular grounds for concern. As Watkins (2013: 36, my emphasis) evokes, 'bloated bodies ... were hauled from the graves, their supernatural corruption, their failure to dissolve naturally in the churchyard earth, but rather to survive and swell, demonstrating their ongoing 
vitality and capacity for harm'. Revenants might also be horribly emaciated yet still lifelike, as in the case of the ghost met by Mr Snowball of Ampleforth who combined the ghastly thinness of the dead with animacy: walking abroad (Watkins 2013: 27). It was thus the corporeal failure to decay properly that could lead to the suspicion that further intervention was required by the living, on behalf of the dead.

In rare monastic accounts, such as those written down by a monk from Byland Abbey in North Yorkshire, this often led to violent solutions: disinterment, decapitation, dismemberment or cremation, even for a 'Christian' body (Watkins 2013: 37). Rarely, this also required removal or reburial in a different locale, as in the case of the revenant priest John Tankerley, who was exhumed from Byland Abbey itself and consigned (at his abbot's behest) in the black lake of Gormire (Watkins 2013: 34), or Abbot Brihtwold of Malmesbury, whose evil disposition and death in a drinking bout led to his exhumation from the consecrated ground of St Andrews and burial in a 'marsh' (Blair 2009). (Note the watery fate of such remains, suggesting a well-practised use of lake, mere or marsh, to deal with the 'difficult' dead). St Etheldreda herself may have been preserved through an uncanny set of coincidences: an aesthete whom Bede assures us ate only once a day, she finally fell victim to a tumour on the jaw, which must have further inhibited ingestion, and was interred in a simple wooden coffin in the marshy ground of the abbey of Ely. Aesthetic lifestyles no doubt reduced bacteria in the stomach that normally initiated decay, while the 'cold storage' effect of a crypt or frozen and waterlogged burial grounds all help explain the preponderance of early medieval 'saintly' incorruptibles (Chamberlain and Parker Pearson 2001: 21). Turner has even suggested that St Edmund's incorruptible body might indicate that it was originally a 'bog body' from the Fenlands, interpreted by its discoverers as the remains of this local saint (cited in van der Sanden 1996: 65). The power of such remains in the medieval period were astonishing: a 'headstrong young man' who insisted on seeing the remains of St Edmund 'lost his mind when it was shown to him', whereas the 'doubting' Abbot Leofstan, motivated in the mid-eleventh century to forcibly test the join of head and body, found his hands to be paralysed and his 'speech and sight' damaged (van der Sanden 1996: 65). By the seventeenth century, however, when our couple from Hope set out as the snow clouds gathered, attitudes towards the miraculously preserved dead had changed.

\section{The 'dangerous dead'}

The split from the Catholic Church that began in England as a political affair under the reign of Henry VIII, was of course part of a much greater process of Reformation across northern Europe, affecting most of the countries within the scope of this study - principally Germany, the Netherlands, Denmark, Sweden, Belgium and Scotland, with Ireland notable for its resistance to religious change. This Protestant faith officially removed belief in purgatory. Such a radical shift 
in eschatology took time to percolate, or rather, to be reluctantly and sometimes violently implemented, at the level of the parish - let alone within the confines of a household dealing with the dying (Duffy 2005; Watkins 2013). While purgatory existed, a corpse that failed to decay or a ghostly apparition that haunted the living could be explained as a being who was delayed or detained (normally through sin) in a place of suffering; their fate could be expediated through prayer, memorial masses, even papal indulgence (Watkins 2013: 50). If all else failed, there was a suite of apotropaically effective measures (usually combining Christian texts or blessed substances with binding prayers, gestures or funereal acts) that were remarkably effective (Gordon 2020). Our Byland Abbey monk made a habit of recording as many as possible (Gordon 2020). This was augmented by what Gilchrist (2008) has described as 'magic for the dead': anticipatory folkloric apotropaism at the graveside that combined the best of both worlds in a mix of material and ritual practices to ensure successful passage into the afterlife or deal with fears about a future restless spirit.

Yet we have already seen a tension emerging in the later medieval period that haunted both clerics and laity through to the eighteenth century, regarding these well-preserved bodies. They might be a 'marvel' as the imagined Saxon congregation described Erkenwald's pagan - they might even be a saint like Etheldreda but others were feared as both bodies and souls that were not at peace and required some kind of efficacious intervention. Reformed eschatology could not explain this phenomenon since there was no purgatory in which to be detained. Worse, what if one could not, now, influence the fate of the deceased through prayer or apotropaic offering? Both the putrescent and incorruptible dead gained a power that was new, dangerous and troubling, and the Reformation had stripped away many of the mortuary techniques and folk methods used to deal with such bodies.

We do not know how many human remains from bogs were uncovered during the sixteenth to the eighteenth centuries, only to be immediately reburied during this turbulent era, not least because antiquarianism itself was in its infancy. The moment of discovery is thus rarely recorded, usually because the finder was a peat cutter or ditch digger and we only hear of those whose discovery reached the ears of a diarist, literate cleric, medical man, gentleman scholar or, in the case of Ireland, the Ordnance surveyors who conducted extensive interviews during the mid-nineteenth century. In some of the earliest records, we sense the immediate effect of such remains on those who discovered them. The Amcotts Woman from the Isle of Axholm in Lincolnshire was found in 1747 by a 'labouring man', when his peat spade cut through the toe of a sandal and a foot. It 'dropped into the cut he was greaving Peat in ... which terrified the Man, and he left it' (Stovin 1747: 571). Even in 1866, the sight of a well-preserved coffin burial in Bressay, Shetland had a similar effect upon the men assisting a figure no less than James Hunt, one of the founders of the Anthropological Society:

When the men who dug up this coffin saw the contents they could not be got to render any further assistance, and declared the sight and smell had turned their 
'insides out', this was, however, purely the effect of imagination. It was with some difficulty I could get them to bring some clean water for me and to deposit it at some yards distant. I had gone to Lerwick for a packing case, and the sailors who brought me over hesitated to take back a skeleton. (Hunt 1866b: 369)

In many instances, it was the clothing or footwear that attracted detailed description and was often retained: a pair of shoes from Hatfield Chase Moss found in the Elizabethan period had apparently hung in the hall of the Trigotts at South Kirby, South Yorkshire (Hunter 1828), but of the body itself we have no record. In 1813, in Drumadreen (Ireland), Robert Fleming and his wife discovered a fascinating long garment belonging to a woman while digging peat. It was retrieved and sold for two shillings and sixpence to be 'brought to Belfast', but the discovery of a puncture wound, a substance resembling clotted blood and locks of hair disconcerted the finders who 'did not make a further search but believe[d] the body or bones are still near the spot' (Briggs and Turner 1986: 190, no. 79). A later entry in the Ordnance Survey Memoirs suggests that someone did indeed return to search again, for a grave in the local farm was reported to contain the body of this woman alongside the hat of a 'Highland soldier' who fell 'in the troubles of 1641' (Briggs and Turner 1986: 191, no. 79). A long wooden sword also reputed to have been found in the bog was long lost. Later Ordnance Survey Memoirs record that the grave was in a dilapidated state ... altogether composed of turf moss. From the beating of the tempests the grave is partly stripped and many of the bones are exposed to wind and weather' (Briggs and Turner 1986: 191, no. 79). We can sense here the power of a degraded bog skeleton to disconcert these early British map makers, trying to chart the fluid boundaries of what must have been to them an unfamiliar and unwelcoming land (see Friel 1980).

Some of these remains were firmly dealt with through the authority of the contemporary church. The Danish discovery in 1797 of a 'small, stocky man' wearing two capes led to the making of a simple coffin and interment in Holbøl churchyard (van der Sanden 1996: 41). A church burial was also accorded to the Korselitse bog find, on Falster island, of a 'strand of long hair', bones, glass beads and a bronze brooch (van der Sanden 1996: 42) - though as we shall see later in the chapter, this was a temporary fate. In the Netherlands, the remains of Terhaarsterveen Man, found in 1891, were 'properly laid in a coffin' before reburial in the cemetery at Ter Apel, scuppering the plans of the museum correspondent, Landweer, to make a full report (van der Sanden 1996: 53). A photograph of the coroner's report reveals that the doctor tasked with this autopsy confirmed that 'the person in question is truly dead' (van der Sanden 1996) - a strange phrase that hints at ongoing concerns with such well-preserved remains, now proved to date between $195 \mathrm{BC}$ and $\mathrm{AD}$ 110. Meanwhile, in the UK, an individual colourfully arrayed in green 'toga', scarlet dress, yellow stockings and fine sandals was found on Grewelthorpe Moor (an upland blanket bog) by the Grainge brothers in 1850. The clothes were associated with flesh 'tanned into a kind of fatty white substance [that] had a very offensive smell' (Lukis 1892: ix). One sandal and fragments of stocking were salvaged 
by the local constable and presented to the Yorkshire Philosophical Society (now in the Yorkshire Museum) but the human remains were buried in the churchyard of Kirby Malzeard (Lukis 1892). The post-mortem claiming of the dead for Christ is also recorded at Grinton in Swaledale, where a bog body was formally recorded as having been interred in the churchyard in 1797 (Briggs and Turner 1986: 146, no. 43). Human remains from Whixall Moss in Cheshire found in 1889 were similarly interred in the local cemetery, as soon the coroner disclaimed any interest in an inquest (van der Sanden 1996: 62). Likewise, the bones and skin of a decapitated individual from Dolfawr Fair in Ceredigion, Wales were reburied in a church at Ystrad Meurig in 1811 (Turner and Briggs 1986: 146, cat. no. 48). In Scotland too, the bog bodies from Hoy (Cowie et al. 2011: 23, cat. no. 11) and Mochrum (Cowie et al. 2011: 34, cat. no. 37) were given 'decent interment' in Christian soil, as Dr James Kennedy - tasked with investigating the former body - put it (in Cowie et al. 2011: 24, 34).

In contrast, the Drumard bog skeleton in Co. Derry, Ireland was 'buried on the site where found' in 1836 (Cowie et al. 2011: 191) and Terrydremont South Woman found with a crutch in the bog in 1832 was 'collected together and buried very deep in the same place where they were found' (Cowie et al. 2011: 192, cat. no. 89, my emphasis). The depth of reinterment may have been part of the strategy through which locals ensured they did not physically or spiritually 'rise again' to the surface of the bog.

A body found in Drumkeeragh, Co. Down in 1780 was the subject of an extended essay by the Countess of Moira (1783) and once again, clothing was retained and analysed while the 'bones were re-interred nearby in the bog' (Cowie et al. 2011: 192, cat. no. 94). In the course of her 'praiseworthy study' and diligent search for remains of body and textile evidence (van der Sanden 1996: 47) she perceptively changed her interpretation of these remains from those of an unfortunate Elizabethan famine victim to someone from the time of the 'druids' (van der Sanden 1996: 48). Meanwhile, a decapitated murder victim found in Flanders bog in 1804 (Co. Derry) associated with a suite of 'deadly weapons' caused 'great sensation throughout the neighbourhood and many persons came to the spot to inspect the body and garment', but 'after some deliberation the body and garment were re-interred near the spot where it was found' (cited in Briggs and Turner 1986: 191, no. 84). In the case of the Mulkeeragh bog 'Highland Soldier' (so-called due to his 'tartan' cloak and uniform dress) found in 1753, the Ordnance Survey Memoirs record:

Many persons came from all parts of the surrounding neighbourhood to inspect the body of the Highland Soldier. They consulted with each other where he should be re-interred and after some hours of deliberation, they came to the conclusion that there should be an inquest held upon it on the spot ... This was considered the more necessary in consequence of the extraordinary state of preservation of both the body and garments .... They agreed to bury the body in the same spot $\ldots$ as nearly as possible in the order in which they were found. (Briggs and Turner 1986: 192, no. 88) 
In Scotland too, oral testimony records immediate reburial in the bog at Foula 5: the remains of a woman were 'put back in the place where it was found' (Gear 1883: 2, cited in Cowie et al. 2011), and at the Gravens (West Liog, Foula 6) the peat cutter reported that after the discovery of a mittened or gloved hand one year and 'fair hair' the next, the remains were 'left where it was, and that end of the bank was left uncut thereafter' (cited in Christiansen 1998). As we shall see in Chapter 4, the giving up of part of an ancestral peat cutting or 'moss room' as it would be known in Lancashire, would not have been lightly done.

There is a sense in many of the above cases that the act of discovery was experienced as a dangerous disturbance of the dead, and that there was something about the locale itself, the original place of 'rest' (even if this followed violence), which should be respected. Even the strange discovery of a complete set of 'intestines' found in 1835 in Camus bog (Briggs and Turner 1986: 190, no. 78) led to their immediate reburial 'in the place where they were found' (Briggs and Turner 1986: 190). Most tellingly, in Bonstorf, Lower Saxony, the discovery of a 'dead man' (now known as Bormwisch Man), whose head protruded from the bog, prompted villagers to consult their local priest, Magnus Lauenrod, as to whether he should be buried in the churchyard. As van der Sanden (1996: 23) records, the priest's response was a curious mix of Christian and folkloric belief: he exhorted them to leave the man where found since the 'elves had pulled him into the bog and would soon pull him down further ... a person who ventured into a place where elves resided had to be possessed by the devil'. The next day, the body had indeed sunk from view. In this unique account, we see a landscape where malign spiritual beings dwelt alongside Christian forces and those who had the temerity to interfere with them should expect such creatures to take their due.

Other bog bodies, such as Rasharkin Man from Co. Antrim (Briggs and Turner 1986: 190, no. 68) and Boghill Man in Coleraine (Briggs and Turner 1986: 190, no. 76) were interpreted by local communities as 'known' suicides and there is no record of them being salvaged for Christ. This is hardly surprising. At the time, many men of the church believed that mysterious or violent death, drownings and especially a suicide, had to be strategically dealt with outside consecrated ground. Ignored by a church that refused to mediate with these dangerous dead, local communities turned to their folkloric knowledge of a landscape pregnant with not just Christian but supernatural forces. For example, in Lancashire in 1800, the servant girl of Dr Ogden from Ashton-under-Lyne was 'deceived by her lover, took poison and died' and was buried 'in unhallowed ground, but at a spot where the holy sign made by the crossroads would deter her ghost from walking' (Bowman 1960: 358). In the adjacent parish in 1774, after the landlord of the Red Lion in Droylsden was found hanged, he was initially buried at the 'Four Lane Ends' on Newton Moor on 31 May. This place combined the symbolic power of the crossroads with the bog, but at 3 a.m. the following morning, his friends exhumed the body and interred it illegally in Ashton parish churchyard. By 13 June rumours relating to this act had reached the local priest and these witnesses were 'compelled to disinter and rebury the corpse in Newton Moor' (cited in Bowman 1960: 358 n. 41). 
In the above examples, the well-preserved dead were a concern not a mere curiosity, analogous to or often synonymous with the suicides, murders and mysterious deaths of the contemporary world, and dealt with in a similar manner. Perceived as potentially malignant, the fear they wrought required skilful Christian or folkloric practice to deal with such 'dangerous dead'. Whether this involved a cleric or the rural poor themselves, it required a respectful understanding of the forces of life and death, a cycle in which the living were precariously and temporarily positioned to intervene. It drew upon an understanding of corporeal 'stuff' as well as spirit: how flesh should decay and why this, quite literally, mattered. It relied on an intimate knowledge of place - where was the right place to do something, given the worlds of the living and the dead. And finally, to be efficacious, it depended on a consummate performance - how to do it well. The risk was that the dead were not quite yet done with the living. As Watkins evokes, 'Disintegration, profane burial and non-burial all hinted at damnation ... Visceral fears were at work under the surface of this folk theology. Dead bodies were numinous things. For a time they still had life in them ... All too lifelike, the dead person seemed merely to sleep' (Watkins 2013: 165).

\section{The stuff of wonder}

Bog bodies did not merely elicit fear. They also inspired wonder. Writing in 1857, William Wilde wrote with awe of the Castlewilder bog body, Co. Offaly, found with shoe, woollen garments and 'an abundance of long, black hair on the head ... decorated with golden ornaments' (cited in Briggs and Turner 1986: 194), going on to note both 'the mystery attending this discovery and the endeavour to conceal the body'. At West Tofts in Norfolk, an 'oaken coffin' yielded bones and ' 30 small beads' (of blue glass) with a 'black face of Lancashire coal, a golden funnel and a cipher' (Norfolk SMR no. 5137, cited in Briggs and Turner 1986: 185, no. 31). In 1824, at Kentucky on Pilling Moss, Lancashire, the local historian Birch described the discovery of a 'piece of coarse woollen cloth, of a yellow colour ... in which were contained, the remains of human skull, with a great abundance of hair, of a most beautiful auburn, and two strings of large black glass beads, together with a part of the first vertebra of the neck' (letter dated 4 June 1824, cited in Edwards 1969: 101-2). The description fits a decapitated head, wrapped in cloth but with a necklace apparently interred with it - in a subsequent letter he describes two strands: one of jet beads half an inch in length and cylindrical in form, the second strand of more irregular length jet beads alongside a large, round amber one (letter dated 5 February 1825, cited in Edwards 1969). Birch goes on: 'the hair was plaited, and of great length; in many parts, about three inches from the extremities of the braids, it was cut off ... the ends were exactly level, not a hair projecting' (letter dated 4 June 1824, cited in Edwards 1969: 102). Over the wrapped head, he records a sod of turf, 'bearing evident marks of being cut with a spade', covered over by the solid mass of subsequent peat (cited in Briggs and Turner 1986: 184, no. 22). 
Whether the Burwell Fen bog body ever existed or not is much debated (see Briggs and Turner 1986: 181) but the way in which it was evoked by the author and early broadcaster Wentworth Day tells us much about the affect people associated with such remains. He describes the 'Ancient Briton' standing upright in a dug-out canoe and garbed in leather jacket and belt as 'most shudderingly entrancing ... [the] lank black hair dropped to his shoulders ... his right arm raised as though about to cast a spear' (Clarke 1960). Like the Erkenwald pagan, however, he apparently 'crumbled to dust in the sharp Fen air' (Clarke 1960). Other fantastical finds include that of Solway Moss, where sometime before 1772, peat diggers claimed that they had found 'a man and horse in complete armour' noting 'the skeleton of each was well preserved and the different parts of the armor [sic] easily distinguished' (Gilpin 1786, cited in Lyell 1838: 724). The find was thought by locals to be one of a troupe of Scottish cavalry, driven into the morass during the Battle of Solway in the reign of Henry VIII, c.1542.

In Scotland itself, the turbulent history of the 1600s-1700s provided a ready set of explanations for bog bodies, who were variously linked with Scottish and English battles (Alford, Aberdeenshire: Cowie et al. 2011: 26, cat. no. 22; Kilsyth: Cowie et al. 2011: 27, cat. no. 25), inter-clan violence (Torr na Cabar, Argyll: Cowie et al. 2011: 27, cat. no. 23) and the execution of Covenanters (Moorscalloch Moss, Kirkcudbrightshire: Cowie et al. 2011: 36, cat. no. 40; Carsgailoch Hill, Ayrshire: Cowie et al. 2011: 30, cat. no. 32). The religious 'martyrdom' of the three Carsgailoch men, shot on this upland bog for their beliefs, may explain why fragments of clothing and locks of hair were taken as relics. Fragments were also taken from the Berrybrush bog body (Cowie et al. 2011: 30, cat. no. 33), interpreted as a local herdsman who had committed suicide and found with a rope around his neck. Pieces of cloth and long yellow hair were cut and sent to men such as James Hogg, the 'Ettrick Shepherd', who wrote an account of the discovery and the 'fragments of these enchanted garments' (Cowie et al. 2011: 31, my emphasis). The keeping of these latter quasi-relics suggest a perceived apotropaic power: materials that defied the decaying hand of time, perhaps because they were associated with the sudden succession of life.

Another example of the acquisition of clothing from a bog body was written by the Countess of Moira (the first female author to address this phenomenon) as discussed above. She conjures the delicate beauty of 'gauze-like drapery ... brightpale green, of a most beautiful colour, and of a light and delicate texture, though woven in troilled work' as well as two plaits of hair from Drumkeragh in lreland (Moira 1785: 93). Her interrogation of the finder (initially 'rewarding the man beyond his hopes') then took a strange turn (Moira 1785: 93). When she pressed him on whether any implements or weapons had been found with the body, 'he became terrified, and grew so cautious and undecisive in his subsequent answers' that nothing further could be gleaned (Moira 1785: 94). He was apparently frightened by the story of a local man who was also rumoured to have found a great 'treasure' in a nearby bog, which led both to a suspicious rise in his personal fortune, and a subsequent spell in gaol (Moira 1785: 94n.f). Moira realised he feared 
a similar fate, and did not press him further but her suspicions may have been well founded, for when she sought to 'revive' a piece of fabric 'originally ... of a red dye' there 'resulted a precipitation of verdigrease' that she suspected was from 'having lain in contact with some implement of brass or copper' (Moira 1785: 93). This diligence with which she pursued this discovery and the wonder it incited in her still impresses. Secular well-preserved 'relics' were sought after. Countess Moira herself removed a lock of hair from the tomb of Humphrey, Duke of Gloucester, lying in his crypt in St Albans, in the year 1747; later noting that it had the same hue as the hair from her bog body (Moira 1785: 104n.r). She states that it was 'so perfectly Strong, I had it woven into Bath rings [a piece of mourning jewellery, usually fashioned from a loved one's hair]' (Moira 1785: 104n.r).

For some, the power of these remains lay not in their ability to awe but the perception that magically or mysteriously preserved bodies somehow concentrated life force, giving them protective or curative properties. Egyptian 'mumia' had long been renowned as a medicinal cure-all: French king Francois I carried a concoction of mummy and rhubarb with him at all times (van der Sanden 1996: 43). Like mummies, the remains of those who died sudden or violent deaths on the gallows were also sought after, so long as their body parts could be swiftly procured from the still-twitching corpse, such as the fabled 'Hand of Glory' (Watkins 2013). Indeed, the final part of Coles's (1657: 32) chapter XV on mosses in his herbalist tract describes the peculiar power of 'dead Men's Skull' moss, which should preferably have grown upon 'Skulls of those which have died by a Violent Death'. Though 'rare, and hardly gotten' in his times, he noted it was a key ingredient in 'Unguentum Sympatheticum, or Weapon-Salve, which cureth wounds without locall application' (Coles 1657: 32). The notion of sympathetic magic here is key. It was to become a favourite medicine of King Charles II, who bought the recipe from a physician, Goddard, and practically patented this 'remedy' as 'the king's drops' (Sugg 2011: 96). It is no wonder that parts of well-preserved bodies from the peat thus began to gain a similar reputation as these other substances, with an apparent power over both time and mortality. Kibbelgaarn Man and the Bourtanger bog body in the Netherlands in the late 1700s, and Ahlintel Man dating to 1794 as well as the Obenaltendorf skeleton dating to 1895 (both from Germany) were bought, pulverised and sold as cheap alternatives to the Egyptian mumia (van der Sanden 1996: 39, 43; Lund 2002: 28). It was against the background of such evocative accounts and folk practices of the eighteenth and early nineteenth centuries that a different voice of authority began to emerge: a voice that in many cases took literal possession of these remains.

\section{Dissecting bog bodies}

The fears of the peat diggers who disturbed the dead and the hopes of those curating an enchanted token or ingesting the pulverised remains of them, are largely recorded by men and women for whom this seemed risible. The antiquarians who 
documented these discoveries (e.g. King 1685; de la Pryme 1701; Stovin 1747) were educated middle- and upper-class scholars, clerics, landed gentry, independent gentlemen, doctors and surgeons (Pearce 2007). Many of them had an explicit medical interest in the human body. Others were more fascinated by antiquities - collections gleaned from travel abroad or perambulations around their own county, district or country (Trigger 2006). Early 'cabinets of curiosity' had morphed into more formal collections, to which these individuals were eager to add new novelties (Bennett 1995; Pearce 1999). Across northern Europe, in their scientific, medical, ethnographic or archaeological meetings, they jostled for renown through the acquisitions of things or knowledge. Wealthy scholars might commission or publish their own volumes and pamphlets, contribute to journals or have letters read to a society (such as Countess Moira (1783), whose letter was read by a Mr Barrington; or Hunt's (1886a, 1886b) letters). Their personal diaries and correspondence evidenced their illustrious scholarly networks (e.g. Leigh 1700; Gough 1768): collaborative communities that were the product of the Enlightenment, informed by the paradigms of rational and scientific thought and the methods of observation, analysis and comparative study (Porter 2001).

The marvel and wonder of the bog body still lay at the heart of many of these accounts but rarely featured as its main subject, being nestled among records of artefacts, leather or textiles, animal remains and trees found in the mosses and mires. One of the earliest detailed accounts of bog bodies was provided by William King in his 1685 letter to the Dublin Society, exhorting the improvement of the peatlands, in which he notes, almost incidentally: 'I know not if it will be worth the observing, that a Turf-bog will preserve things strangely, a Corps will lye intire in one for severall Years; I have seen a piece of leather pretty fresh dug out of a Turfbog, that had never in the memory of man been dug before ... Trees are found, and intire in them' (King 1685: 953-4). For the 'ignorant vulgar' as King puts it, these deep deposits of ruined trees were evidence of the biblical 'Flood' (King 1685: 954), but many scholars posited a more recent date for these deposits. In Charles Leigh's Natural History of Cheshire, Lancashire and the Peak (1700), he describes a series of finds from Martin-Meer including well-preserved trees (discussed further in Chapters 3 and 4), which caused him to doubt the interpretation that they were the result of 'Noah's deluge'. As if in afterthought, he adds, 'One thing had almost slipt me, how sometimes in Mosses are found human Bodies entire and uncorrupted, as in a Moss near the Meales in Lancashire' (Leigh 1700: 65, original emphasis).

Writing about Hatfield Chase, Abraham de la Pryme (1701: 981) also described the 'infinite Millions of the roots and bodies of Trees of all bignesses', many of which were 'black as ebony, and very lasting and durable'. De la Pryme (1701: 988) was particularly taken with the idea that the trees were the work of Roman deforestation as the conquerors improved their new territories and removed the woods that might harbour further resistance. He then continues:

That which is also very strange, is that about 50 years ago, at the very bottom of a Turf-pit, was found a Man lying at his length, with his head upon his Arm, as in a common posture of sleep, whose skin being as it were tann'd, by the More 
Water preserved his shape intire, but within, his Flesh, and most of his Bones were consum'd and gone, an Arm of whom one of the Workmen cut off, and brought home to his Master, which is now in the possession of my honoured Friend, and great Antiquary, Dr Nat. Johnson, whose Antiquities of this country are earnestly inspected by all Ingenious Gentlemen. (De la Pryme 1701: 983)

Sadly, Johnson suffered a fall from political grace, becoming in de la Pryme's words 'exceeding poor' (cited in Hunter 1830: vol. I: 39n.). Ralph Thoresby (a fellow of the Royal Society) noted after a visit in 1695 that he was 'by his unhappy circumstance ... little better than buried alive' - a strange phrase given the bog arm in his collection, which was left in Pontefract and would have been seen by Thoresby himself in 1703. Afterwards, Thoresby wrote: 'Went to view Dr. Johnston's collection of natural curiosities, which has been very considerable: there yet remain some things which are very remarkable, but in very ill condition, exposed to injuries in more ways than one' (cited in Hunter 1830: entry for 1703 April). The Hatfield arm is a microcosm of antiquarianism: human remains valued as a marvel, exchanging hands between working-class labourer to landowner, to gentleman scholar where they helped secure his intellectual fame, but frail to the fortunes of this individual and thus lost to posterity. Meanwhile, the shoe and foot of Amcotts Woman, which so shocked the Axholm peat digger, merely excited the interest of the antiquarian Stovin, who sent them to the Royal Society, also enclosing a second sandal 'whole and firm ... with all the Bones of that Foot found in it, and the Grisly part of the Heel' (Stovin 1747: 572). Other parts of the body and hair confirmed this to be the burial of a woman, whose arm resembled 'the Top of a Muff or Glove, when the Bones were shaken out' and he also forwarded a hand, 'with the Nails as fresh as any Person's living', though he noted ruefully that the skin of the hand had been 'stuffed ... having suffered by the Spade' (Stovin 1747: 572). His purpose in enclosing these relics was clear: 'I want to be informed what Age they wore those sandals in ... and by what Nation' (Stovin 1747: 572-4). They were then taken across the quad to the Society of Antiquaries, and the note appended to the publication of this communique states: 'When the above Letter was read at the Society of Antiquaries, there was produced the Hand of the Woman therein mentioned, and a Sandal or Shoe taken from one of her Feet ... This being of an ancient Form, the Society order'd an exact draft to be taken of both that and the Hand' (Stovin 1747: 575).

We might imagine the atmosphere in the Society of Antiquaries on 1 October 1747, when it is minuted by the Secretary, Mr George Vertue, that seven gentlemen sat around the table to inspect these peat-stained artefacts and body parts. Long believed to be lost (Turner and Rhodes 1992: 78n.10), the watercolours produced from that evening by Vertue himself (Figure 2.1) capture more than the formal engraving of the shoe published in the Philosophical Transactions of the Royal Society. The reddish colour of the lace weaves in and out of the scalloped loops of her sandals, to 'close them at the toes like a purse' (Minute Book of the Society of Antiquaries: vol. V: 1 October 1747). The watercolours of both this and the sandal were glued into the accompanying album where they 


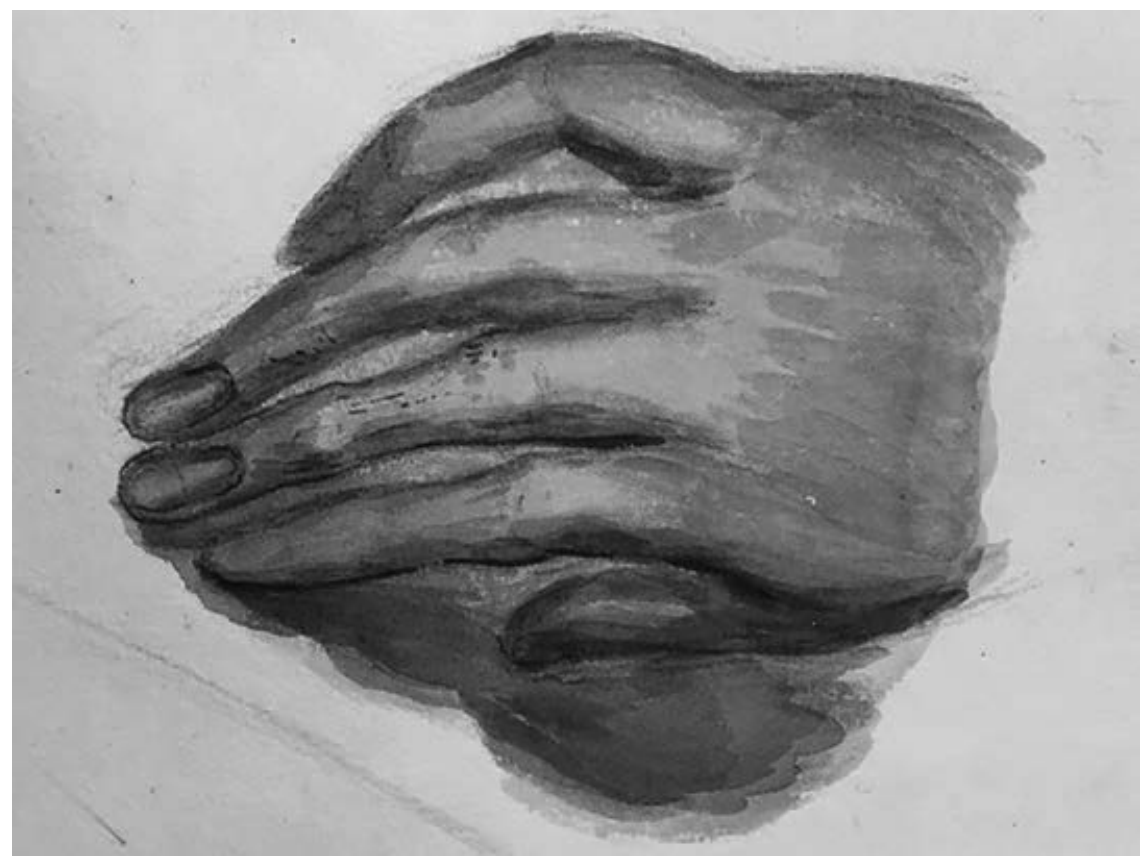

\begin{abstract}
2.I The hand of Amcotts Woman from the 'Prints and Drawings Collected Before 1750' of the Society of Antiquaries, linked to Minute Book entry October 1747: 33-4. All rights reserved and permission to use the figure must be obtained from the copyright holder.
\end{abstract}

have lain unseen and unknown since then, as far as I can tell, representing the earliest representation of a bog body, even if it is merely a hand. Trapped between plans of Roman villas, architectural facades, images of heraldry and castle elevations, the picture is altogether too human somehow. The delicate fingers and nail beds curl inwards slightly, on to the palm, the hand is small, shrunken by the 'morass' or 'more' as they describe it (Society of Antiquaries, 'Prints and Drawings Collected Before 1750', vol. V: 34). These human remains fascinated yet appalled; they were not yet a subject fit for public reproduction, and have never before been reproduced.

This distaste is embodied in a remarkable letter by Mary Wollstonecraft, author and defender of women's rights (Sanders 2009). Despite her progressive views in many areas, Wollstonecraft derided attempts to preserve the corpse, such as the mummified remains in a vault in St Mary's, Tonsburg, Norway (now demolished), which she saw in 1796:

A desire of preserving the body seems to have prevailed in most countries of the world, futile as it is to term it a preservation, when the noblest parts are immediately sacrificed merely to save the muscles, skin and bone from rottenness. When I was 
shown these human putrefactions, I shrunk back with disgust and horror. 'Ashes to ashes' thought I - 'Dust to dust!' - If this be not dissolution, it is something worse than natural decay. It is reason against humanity, thus to lift up the awful veil which would fain hide its weakness. (Wollstonecraft 1976: 71)

Her daughter, Mary Shelley, would go on to write Frankenstein: an early Gothic ghost story, written on the shores of Lake Geneva in the company of the Romantic era poets Byron and Shelley (her future husband). Mary Shelley was in wonderment of the kinds of modern science practised by Galvani and Volta, in their demonstrations of animal and metal-induced 'electricity'. Although her mother died soon after her birth, she may have known of her mother's letters and clearly enjoyed her own creative 'experiments' that mused on whether the living should really intercede with those already consigned to death. Both women lived on the cusp of an era in which the anatomical scrutiny of human remains was controversial. The legacy of Christian beliefs about maintaining corporeal integrity in the hope of final resurrection lingered. The procurement of enough suitable dead bodies for both research and training was still a problem for the medical profession, yet public dissections were not only attended by physicians: the enlightened public enjoyed this as a spectacle as much as a scientific endeavour. The judiciary of the day believed this could have a moral as well as medical purpose and helped sanction certain kinds of corpses for examination through the revision of the 1752 Murder Act, which stated that no body of a convicted murderer should be permitted burial (Watkins 2013: 161). This expanded the remit of a judge to pass a sentence of 'death and dissection' not only to murderers but lesser felons, condemning them to the 'added terror' of a post-mortem afterlife as medical specimen (Watkins 2013: 162). It is no surprise then that bog bodies were seized upon for further opportunities to dissect and examine the human corpse. The remains of a bog body from a peat moss in Whitaside (Grinton in Swaledale) were eagerly examined by the triumvirate of 'Messrs. Barker, Thompson and Metcalfe sugoones [sic]' (Grinton Parish Registers, cited in Briggs and Turner 1986: 186). Stovin (1747) himself clearly had no qualms in rendering parts of Amcotts Woman limb from limb for further analysis. Reports on these remains allowed the scientist Charles Lyell to contemplate the antiquity of the discovery: 'six feet under' the peat, with 'antique sandals ... [that] afforded evidence of her having been buried there for many ages', while puzzling over the fact that 'her nails, hair, and skin, are described as having shown hardly any marks of decay' (Lyell 1838: 22). On Shetland, Hunt's trench-side de-fleshing of the Bressay bog body must have shocked his peat diggers: 'In cleaning the skull and long bones I found considerable difficulty, and also in separating the skin and muscles of the arm from the bone. I had an easy task scalping the long sought for treasure, and found that with one good grip I had a pretty good wig in my hand' (Hunt 1866b: 369). The record of his discovery in the Anthropological Society records he 'then exhibited' the remains to his colleagues, leading to a vigorous debate over both the variable preservative properties of peat and, as we shall see in what follows, the racial identity of the deceased (Hunt 1866a: ccvi). 
It is at this point then that bog bodies (as well as more skeletonised body parts) started to enter antiquarian or medical museums. One major collection was the Sedgewick Museum (later the Duckworth and Shore collection) at the University of Cambridge, containing remains from Burwell Fen, Shippea Hill and Reach Fen, as well as select examples from Lincolnshire and Lancashire (Briggs and Turner 1986 181-2). The Museum of the Royal College of Surgeons (now the Hunterian Museum) received remains from Birkdale in Lancashire and Smallburgh in Norfolk (Briggs and Turner 1986: 184-5), as well as Clywd in Wales (Briggs and Turner 1986: 187). Some were gifts, as in the Northamptonshire frontal and parietal bones 'from a peat bog' bequested by J. Prestwich, Esq. (Briggs and Turner 1986: 185, no. 40). The Geological and Polytechnic Society of the West Riding preserved its own skeleton from Austwick Common, in North Yorkshire (Briggs and Turner 1986: 185, no. 41). Meanwhile, it took time for the Natural History Museum in London to acquire the remains from Scaleby Moss in Cumbria. Excavated in 1845 , this black-haired body wrapped in a deer skin and 'holding' a thick stick was bought by the antiquarian Thomas Bateman in 1853 and sold as lot no. 428 upon his death forty years later (apparently to a collector named 'Rathbone'), before final bequest or acquisition by the museum (van der Sanden 1996: 45, fig. 50). This pattern of acquisition is repeated across the institutions of Ireland, Denmark, Germany and the Netherlands. The Bareler Moor body for instance, was nearly complete when discovered in 1784, but was dissected and distributed to 'different interested scholars' (van der Sanden 1996: 40).

We can thus locate this era of bog body discovery and research within the Enlightenment's rational, scientific methods and an exhortation to understand organic life through close inspection, dissection and analysis. Following the work of Descartes, the human body was now seen as analogous to a machine, whose processes of growth, decline and eventual decay could be studied and charted (Robb and Harris 2013: 24, tab. 1). Yet well preserved bodies demanded further examination and explanation: was their fleshy survival an attribute of the corpse itself or its depositional context? As the title of Hunt's (1866b) article makes clear ('Observations of the Influence of Some Kinds of Peat in Destroying the Human Body, as Shown by the Discovery of Human Remains Buried in Peat in the Zetland [sic] Islands'), some antiquarians and ethnologists were aware that while peat could preserve human remains, this was not a universal characteristic. Variation between adjacent bodies and even within a single corpse was noted, with some limbs better preserved than others; better survival of hair and nails, as well as the flesh of the body; and sometimes, textile or hide fragments associated with clothing or wrapping. However, many of these writers commented on the lack of good bone preservation, rendering such remains pliable, floppy and disconcertingly malleable.

All of these themes can be seen in the account of the Hope couple. Dr Charles Balguy (1735: 413) noted that while it was 'very common to see dead bodies preserved by Art; But that they should lie unchanged by means of the Soil in which they were Interred, will appear Strange to most People. His account, written as a 
young man, did not dwell upon the personal circumstances of the Hope couple he was honed by his scientific training to report on both the detail and causes of their preservation, for the audience for whom he was writing: the Royal Society. He lived at a time of increasing experimentation with embalming methods and when other well-preserved bodies were the subject of scholarly discourse and acquisition: the saintly remains that opened this chapter, lime-encrusted Romans from stone sarcophagi or the Egyptian mummies that were also unwrapped on the autopsy tables (Riggs 2014). As Balguy records, after the initial curiosity of reopening the improvised grave for this couple, there followed a twenty-year period of repeated exhumation to satisfy the curiosity of people from near and far (see Chapter 8). In 1716, they were seen by a Dr Bourn of Chesterfield, who reported that the 'Man was perfect, his Beard strong ... his Skin hard and of a Tann'd-leather Colour, pretty much the same as the Liquor and Earth they lay in' (cited in Balguy 1735: 414). The woman was much less well preserved, by dint of more vigorous inspection: she had 'by some rude People ... been taken out of the Ground, to which one may impute her greater Decay' (Balguy 1735: 414). Dr Bourn himself was not beyond some relic taking: 'He took out one of her Foreteeth, the upper part of which, as far as was contained in the Socket, was as elastic as a piece of Steel; and, being wrapp'd around his finger, sprung again to its first form. But this Power was lost in a few Minutes after it had been in his Pocket' (cited in Balguy 1735: 414). Balguy (1735: 414) also notes that 'People had cut away the greatest part [of their Cloaths] [sic] to carry home as a Curiosity', in a passage that evokes Countess Moira's exasperation in trying to retrieve all the textile fragments from the Drumkeragh bog body, many of which had been taken 'by different people soon after they were found' (Moira 1783: 91). Meanwhile, the young curate sent to oversee their final exhumation, Thomas Wormald, told Balguy that 'the Joints played freely and without the least Stiffness' (cited in Balguy 1735: 415). In his own affidavit, preserved in fine copperplate in the Derbyshire Record Office archives (Figure 2.2), he gives a fuller description:

I was the Person that Buried these two Persons who lay for ye space of 48 years in the Moss \& afterwards were taken up \& brought to the Parish Church of Hope in the county of Derby, to have Christian Burial ... I had the Curiosity myself to go to the place \& see 'em taken up, \& do affirm that it was solid \& firm \& so were all those parts of the Body which were never expos'd to the Air by being gaz'd upon.'

(Wormald 1758, D.1828 A/PI 449/1, see Figure 2.2)

Despite their 'decent funeral' (Balguy 1735: 414), there is no official record of the interment in the Burial Register itself. Rumours of the phenomenon travelled and it seems that in 1760 Wormald was asked to write a personal letter to the antiquarian Samuel Pegge, about the case (originally filed in volume V of Pegge's correspondence but apparently not preserved among the four bound volumes of letters acquired by the Bodleian Library). Instead we must rely on the full transcription of this letter by Charles Cox in volume 2 of Notes on the Churches of Derbyshire (1877), where Wormald reconfirms his observations that 'those parts of 


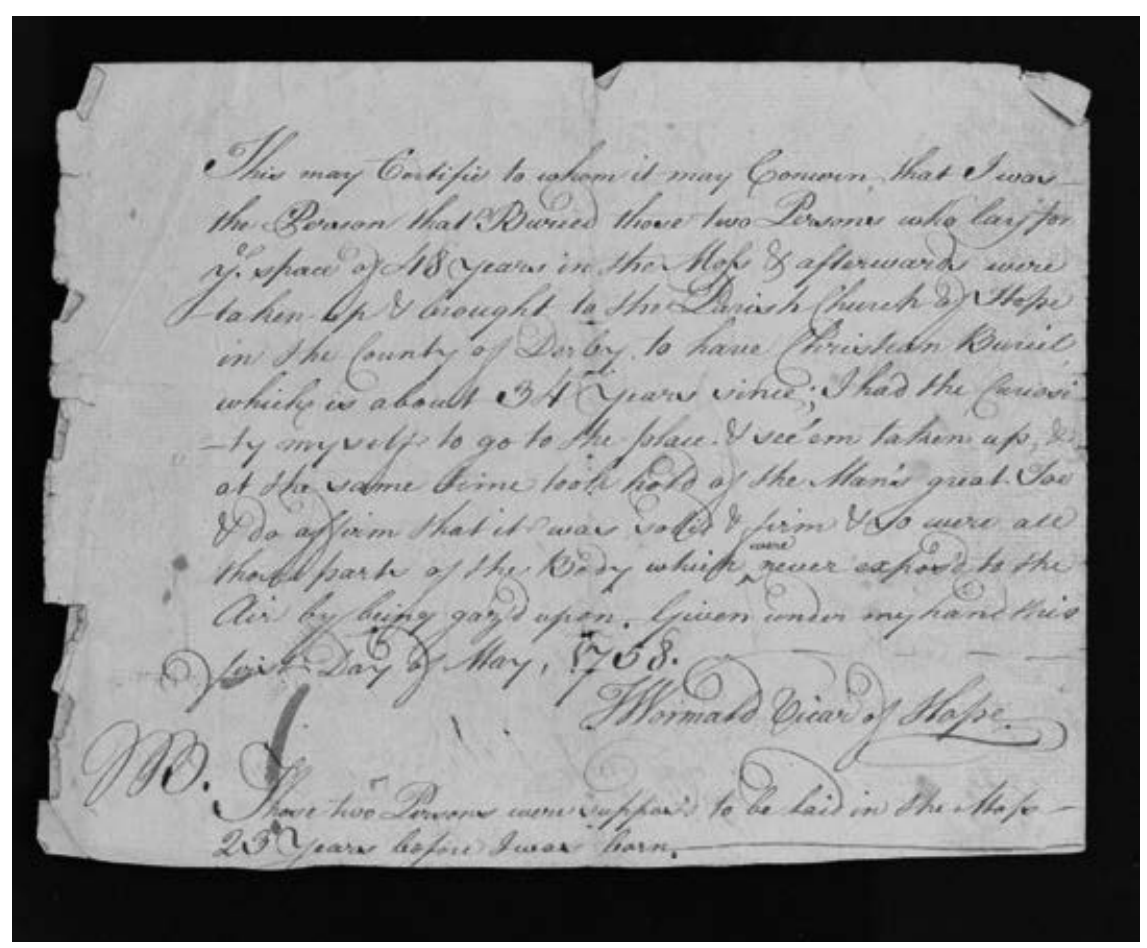

2.2 Affidavit written by Rev. Thomas Wormald,Vicar of Hope, relating to the Hope couple. All rights reserved and permission to use the figure must be obtained from the copyright holder.

ye body that had never been exposed to ye air were as entire and firm as when they were lay'd in, the other part of ye body that was exposed to ye air by opening so often were putrified and gone, only the bones and joynts hung together'. He signs off this account: 'This is a matter of fact and you may rely on it as such from, Your faithful friend and very humble servant, S. Wormald' (cited in Cox 1877: 267).

The vicar was not expressing sentiment or even religious feeling about these bodies; he was using his authority, position and skills of accurate observation to give weight to the veracity of this account. This was how science was conducted: established as a matter of fact not mere wonder or rumour. Yet notably, their remarkable preservation and unsettling power still demanded Christian intervention to assure the living that they had been appropriately dealt with. Huldremose Woman, for instance, was temporarily buried in the local churchyard, although her marvellous clothing was cleaned and dried on the washing line of the local doctor (National Museum of Denmark 2019). Fear lingered still, magnified perhaps by the kinds of places in which such remains were found. Yde Girl from Drenthe, for instance, was found in 1897: a well-preserved young woman, covered by a thin robe-like 
garment, with a tightly wound strip of fabric around her throat and a cut hank of hair laid at her side. The peat diggers apparently cried 'I hope the Devil gets the man that dug this hole', and fled the scene, rendered speechless by their gruesome discovery (Beuker 2002: 107). Over the next hundred years, more accounts of such peat bodies would emerge, but, as Watkins (2013: 164-5) observes: 'Apprehension that the body itself might return to life, might turn into a vengeful revenant, had evaporated by the nineteenth century but unusual corpses were still thought by some to be charged with special powers'. It was only with the creation of wider private and museum collections of such human remains that an altogether different value began to be attributed to these bodies, focused not on their remarkable tissue but the bony matter within their well-preserved heads.

\section{Bog body crania: nation states and racial histories}

The exact date and circumstances of the discovery of Ashton Man (Figure 2.3), described in the Preface of this volume, are at present unknown. As far as we know only a cranium was found, making it a likely candidate for a decapitated but perhaps slightly decayed 'bog head'. There were growing reasons, however, for selectively retaining just the skull. Its discolouration and staining support the provenance of Ashton Moss and it is thus (as the table drawn together by Duckworth and Shore (1911) describes) a classic example of a 'cranium from peat deposits'. It entered the Anatomical Museum at the University of Cambridge sometime in the mid to late 1800 s, where someone elegantly inked upon the forehead the accession number ' 658 ' (Figure 2.3). The archival records indicate that it was donated by Sir Alexander Binnie (Nevell pers. comm.), a British water engineer, whose hydrological infrastructures for London survive to this day. How did he come into the possession of this Lancashire head? As a young man, he was briefly articled to Mr J. F. La Trobe Bateman until 1862 (Grace's Guide 2019). During this time, his master was completing the waterworks supply scheme for Manchester, which included cutting through Ashton-under-Lyne. It is possible that in this brief period at least one 'bog' head came to light, though there is no record of it in the local newspaper, the Ashton Weekly Reporter, and Stalybridge and Dukenfield Chronicle which did elsewhere (Anon. 1869: 2), report the find of an Irish bog body at Morville. La Trobe Bateman's maternal grandfather was a well-known Moravian minister from Ashton-under-Lyne, and the young John Frederick had been sent to the Moravian school in Fairfield, Ashton-under-Lyne, to study during which he might have acquired such a find. The 'heads' from the mosses hereabouts might thus have been in the possession not of Binnie but of his master's family, or some other renowned cleric or schoolteacher living on the edge of this distinctive landscape, and thence passed into his hands.

In later life, Binnie certainly corresponded with archaeologists such as Sir John Lubbock (Lubbock n.d) on antiquities from the London gravels or depths of chalk in boreholes, so perhaps he had always had an interest in the past. His son studied the Natural Science Tripos at Cambridge University and it is highly likely that it 


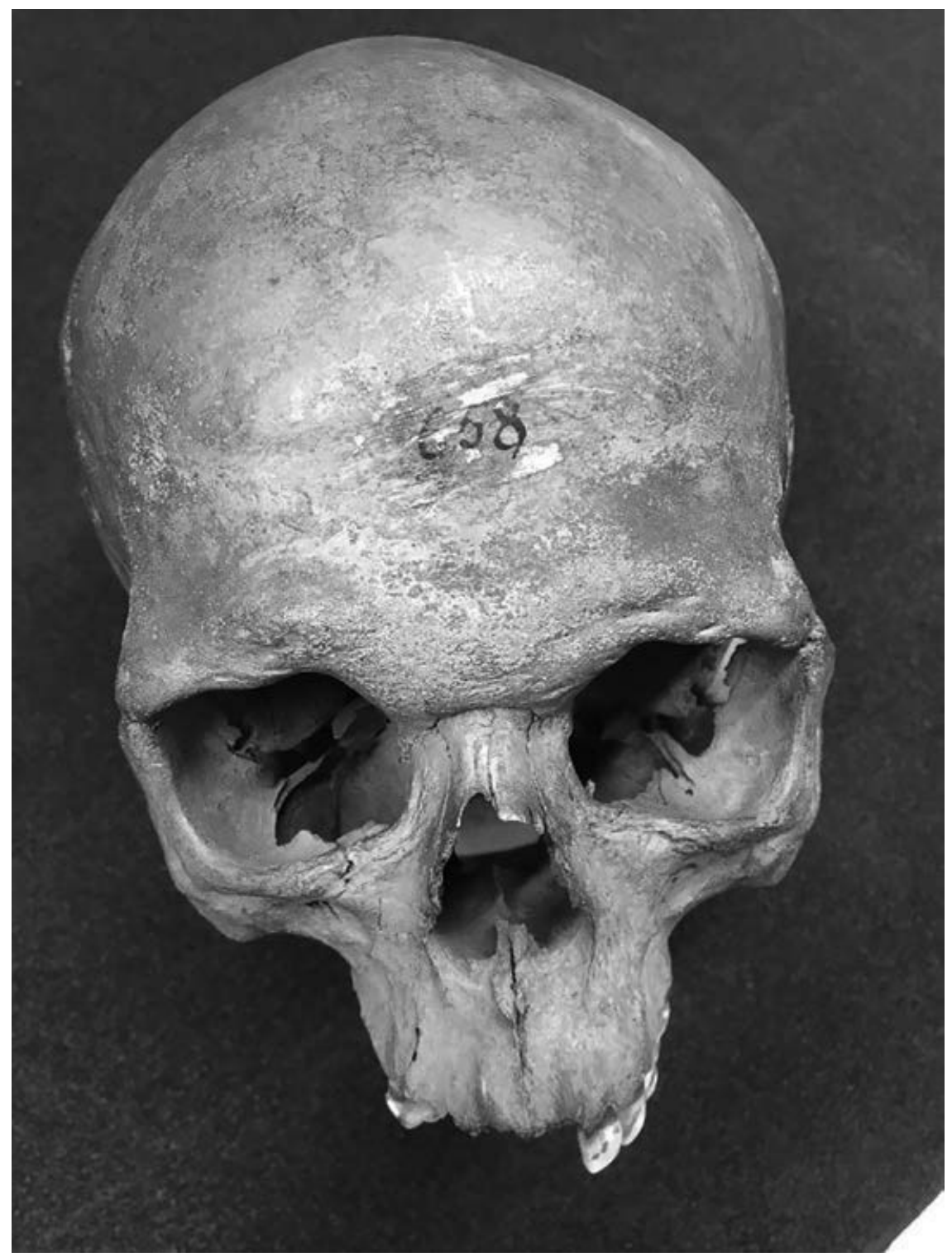

2.3 The Ashton skull, no. 658. All rights reserved and permission to use the figure must be obtained from the copyright holder. 
is at this point that the Ashton head was given to the growing collection of crania that may have been part of the teaching materials that Binnie's son used. Perhaps the 'donation' was a means of currying favour or earning the gratitude of his professors at the time; these would have included Professor Alexander Macalister and Hughes (respectively, chairs of anatomy and geology). It is these scholars that W. L. H. Duckworth and L. R. Shaw thank profusely for access to the 'peat skulls' from the Sedgwick Museum collections (including another, no. 659, from a 'peat moss' in Lancashire, 'locality and description as in the case of' no. 658 (Duckworth and Shore 1911: 134, sec. I). This gives us two heads from the mosses surrounding Ashton and Droyslden Moss. Duckworth and Shore studied a total of eight other 'peat deposit' heads: five of them from Cambridgeshire (mainly Burwell Fen) and the others from Lincolnshire and Norfolk (recognised as authenticated 'bog bodies' in Briggs and Turner's Gazetteer of 1986: nos. 1, 26 and 28). The Kilsyth skull from Stirlingshire, 'black from the action of the peat' (Cowie et al. 2011: 27, cat. no. 25) also found itself in the hands of the Edinburgh Phrenology Society by 1851 , where it was recorded by none other than Daniel Wilson (1851) who used both archaeology and ethnographic analogy alongside linguistics, to chart the 'history' of the peoples of Scotland. Indeed, there seems to have been an avid collector of peat heads by the name of Dr Scott, who acquired two further skulls from Linton Loch (Cowie et al. 2011: 33, cat. no. 35). Yet where these skulls survived, they were swiftly cleaned of any flesh: literally scraped to the bone, in order to reveal the anatomy underneath. This was the case in other countries too such as Denmark, where as late as 1942, the National Museum had a policy of 'clean[ing] the bones of bog bodies of any soft tissues before, in the form of a skeleton, these were handed over to the Normal-Anatomical Institute' (Fischer 2012: 101-2). The very phenomenon that made them notable, infamous even, and drove their recovery, reporting and collection was now stripped away to reveal something more essential about the individual. That essence was 'race'.

Craniology was the technique of measuring human skulls to reveal their racial or ethnic type, emerging in Scandinavia in parallel with Thomsen's artefact-based, typological approach (Morse 2005: 98). It was Eschrict's invention of the cephalic index that particularly caught the imagination of British scholars, publicised as a comparative ethnological method alongside linguistics by Pritchard in his fourth edition of Researches into the Physical History of Man (1841). As Morse (2005) has convincingly argued, it was the craniological technique that drove not just early arrangements of archaeological material in Britain but the collecting habits of its antiquarians. Its advocates believed that 'typical ethnic peculiarities' visible in the skull were 'not transmutable between the races' (Davis and Thurnham 1865: 2). This was part of a much wider global study of human variation within the context of colonial encounter and the problematic use of physical evidence to naturalise and justify the rule of one race over another (see Robb and Harris 2013: 24, tab. 1). While using crania in a limited way himself, Pritchard (1843: xxi) lamented that there was no 'national collection of the sepulchral remains of our ancestors' in contrast to both Scandinavia and Ireland, the latter being diligently assembled 
through the work of William Wilde. This vision was realised over the next few decades in part through the barrow digging of Thomas Bateman and the synthesis of material by Davis and Thurnham in their volume Crania Britannica (1865). The latter two authors were explicit about their aims here, citing the controversial work of Knox that the Celt (conceived in their work as one of the primary prehistoric races of Britain) 'was, as a race, inferior to the Saxon', making explicit links between prehistoric skulls from northern Britain, Ireland and the Hebrides with the 'most barbarous of contemporary tribes' (Davis and Thurnham 1865: 66).

These views were typical of the 'polygenists': those that believed races had distinct cultural characteristics, intellectual abilities and predispositions that were racially innate, fixed and unchanging. It was Knox's student, James Hunt, who not only led the splinter group 'Anthropological Society of London' but stripped clothing and flesh from the Bressay body discussed above to get at her skeleton. When Hunt presented his findings to the Anthropological Society of London (of which he was president) heated discussion arose between several members regarding the length and form of the crania (Hunt 1866a). While Hunt himself reported there was 'nothing particularly remarkable about the skull', it having a cranial index of '.76', his colleagues debated vigorously whether this might be a 'Zealander' (Shetlander) or Scandinavian, drawing on comparative measurements of long- and short-headed specimens known to them. One member seemed most put out that Hunt's paper 'conveyed no idea of the period at which they had been buried, nor of their nationality', and as the secretary went on to note, 'these he considered were the whole points of interest in the subject' (Hunt 1866a: ccvii). After further vigorous debate and point scoring about the transverse breadth of Scandinavian skulls, the chair, Mr R. Tate, was required to call 'order'.

It now looks likely that the Ashton skulls (one of which has been firmly dated to the later Bronze Age, see Robinson and Shinwell 1996) were sent as part of this endeavour to trace the racial history of Britain and form a comparative suite of skulls for the international examples also entering Cambridge's collection. When finally studied as a group, Duckworth and Shore (1911: 134) claim their study of crania from peat deposits was 'justifiable', 'for the purposes of description and comparison' since 'in regard to other mammalia the peat fauna is certainly a distinctive one' (Duckworth and Shore 1911: 136). In other words, despite different find-spots, perhaps they expected to unveil some kind of typical prehistoric 'marsh man' race. In this they were frustrated, for the results presented them with a great 'diversity of cranial form' (Duckworth and Shore 1911: 136). They themselves do not use the term 'Celtic'; they noted their probable antiquity and commented they did not consider them to be older than the Neolithic period. However, they did conclude that they were not 'a fair sample of modern British crania' due to their distinct 'bracahycephalic' (i.e. round-headed, foreshortened) qualities (Duckworth and Shore 1911: 137, original emphasis). To the modern archaeologist, the motivation for this study of peat skulls seems suspect. What were they hoping to find out about prehistoric populations that lived in and around the bogs and fens of Britain? To what end were they hoping to put such a study? 
During this period, craniology was fundamental to the histories that were told about how racial types 'changed' over time. Though some scholars attributed this to the influx of more superior groups from the Continent and population replacement, the ambiguity of the cranial evidence frequently led to fraught debate (e.g. between the antiquarians Mortimer, Greenwell and their craniological specialists, see Giles 2006: 298-9). Duckworth and Shore's desire to focus on remains from the peat cannot have been isolated from wider pejorative attitudes to the marsh, mere and bog (which as Chapter 4 will show, was thought of as unproductive and in need of drainage and improvement) - an attitude all too often applied not just to the landscape but to its denizens. They were privileged, elite academics living in a city fringed by the Fens, but they would also surely have been aware of narratives pedalled in the popular press, about the 'bog Irish' for example - this was after all, the beginning of the civil and political movement for Irish independence from Britain. We can only speculate about whether they hoped their evidence would elucidate or muddy the waters of contemporary debates on race, national identity and cultural politics. But what we can note is their belief that the past had the power to answer such questions, mobilising the remains in their care to address them. Another country keen to search for its nation's origins among the prehistoric dead was Denmark.

\section{Queens, sailors and ne'er do-wells: naming the dead}

The discovery of Haraldskjær Woman in 1835, in eastern Denmark, was initially reported by the district physician in matter-of-fact terms. He described her physiognomy (middle-aged, rather corpulent), her teeth (well-worn), hair (long and thick), with fine, small hands ('hardly belonging to someone of the working class') (Christens 1836-37: 166, translated and cited in Sanders 2009: 91). There was an expression on her face of apparent 'despair' that, along with wooden pegs and crooks, staking down her knees, elbows and chest (van der Sanden 1996: 41), led him to believe she had been 'nailed into the mud while still alive' (Sanders 2009: 91). While Christens (1836-37) then offered some astute observations on both the bog's preservative effects and the shrivelling and shrinkage of the body following exhumation, it was not his scientific observations that were seized upon by fellow Danish scholars. Denmark had only regained its sovereignty from Sweden in 1813, and archaeology was playing a vital role in the building of a distinct sense of Scandinavian identity with a long durée (Trigger 2006). Figures such as Thomsen (director of the Museum of Northern Antiquities from 1816 to 1817, see Jacobsen 2004) and his protégé, Worsaee, were the product of a period of investment in archaeological research that was quite distinct from the privately funded antiquarianism of Britain, sometimes state sponsored but also in receipt of royal funds, through the interests of Frederick VI. In contrast to the increased interest in anatomy and craniology described above, Thomsen's Three Age System was not overtly concerned with 'peoples' or their 'migrations' but rather the order 
of successive change, objects and periodisation (Morse 2005: 97). Archaeological evidence assumed a new narrative importance in a country that was in both political and cultural flux, showing the depth of its successive histories in this one region of Scandinavia, revealed increasingly through excavation as well as artefacts (Trigger 2006).

It was as Denmark moved into this period of progressive change that Haraldskjær Woman was reinterpreted as the body of a Norwegian Viking queen named Gunhild (once married to Erik Blodøxse), lured to Denmark in AD 970 under false pretence of marriage. The Icelandic saga (Jómsvíkinga) tells that the Danish king Harold Bluetooth instead ordered her murder and that she was drowned in a deep bog in $c$. AD 977. The philological professor, N. M. Petersen, used a variety of texts, along with place-name evidence (Gutsmose - translated by Peterson as Gunhild's bog) to authenticate the historical connection with this body (Sanders 2009: 92; Ravn 2010: 108). King Frederick VI, fascinated by this apparent connection with ancient royalty, commissioned the crafting of an impressive oak casket to house her remains within St Nicholai Church, Vejle. On open view, this bog body now fell somewhere between a sacred relic and public spectacle, controlled through the sanctity of the Christian Church but uninterred, bringing 'proximity for ordinary men, women and children to a past and a royal body whose physical attraction and legendary power were lost, but whose allure continued' (Sanders 2009: 94). Yet the young archaeologist Worsaee vigorously objected to this arbitrary connection between text and artefact. In a bitter debate with Petersen - a contest of disciplines and the appropriate uses of historical evidence - the remains should, he felt, be allowed to be an 'authentic witness in its own right' rather than be manipulated in a 'beautiful poetical hypothesis' (cited in Sanders 2009: 92). Worsaee's concerns were well founded: in 1977, the body was radiocarbon dated to the early Iron Age (van der Sanden 1996: 41) and Gunhild lost her royal name to become Haraldskjær Woman, still on view in Veijle.

This story epitomises the ways in which bog bodies can be caught up in the search for nation state histories, or to give historical legitimacy to identity of 'a people'. (It is at this point that we need to remember St Erkenwald's pagan Belinius, under St Paul's Cathedral, confronting his Saxon present with the obdurate prehistoric possessor of British soil.). Another Danish bog body, found in 1979 in Undelev Mose (Jutland), led to much speculation as to whether he was 'a Tartar, a gypsy or a member of the Germanic Cimbri' (cited in van der Sanden 1996: 41). We can note the elision here between 'types' of people, ancient and modern, felt to fit the bill of a stocky bog body. Like Haraldskær Woman, his remains were also handed over into Christian care and control, for burial in Holbøl churchyard (van der Sanden 1996: 41). However, another Christian interment of a bog body, from Korselitse (mentioned above), found on the island of Falster in Denmark in 1843, was re-exhumed at the behest of the crown prince, later Frederick VII. By now, these Danish remains had a cultural capital that outstripped any Christian concerns, and the human remains, along with a few glass beads and a brooch, were sent to the museum in Copenhagen. 
Meanwhile, the power of a bog body to attest to an ancient past was not unproblematic. In 1864, a British navvy working on the shoreline of what would become the Leasowe embankment fetched out from the peat what he initially took to be a basin but soon discovered to be a human cranium (Cust 1864: 193). His ganger then extracted the remains of a 'nearly perfect male human skeleton', whose exposed bones swiftly turned from white to inky black (Cust 1864: 194). The local antiquarian, Sir Edward Cust, made careful notes on the stratigraphic position of the body, providing three first-hand testimonies from the navvy, the ganger and the local castle gardener sent to observe both body and find-spot (see Cust 1864: app.). Lying on the blue clays below three to four feet of peat, Cust (1864: 193) concluded that this must represent 'a most ancient inhabitant of our land'. The remains were sent to the Museum of the Royal College of Surgeons in London where they were examined by none other than Charles Lyell, whose research had transformed understanding of the geological time-depth and early human inhabitation of the British Isles. At a subsequent meeting of the Ethnological Society, Professor Busk reported certain 'peculiarities in it [the Leasowe skull] which indicated an original race or savage tribe' (cited in Cust 1864: 194), hoping that in conjunction with other skulls this might help elucidate the 'three tribes by whom Britain was populated before the invasion of the Romans' (Cust 1864: 194; see also Busk 1865). Cust himself dismissed a relationship with Roman finds from the nearby Cheshire sea-coast complex of Meols, concluding from the deposits that he was dealing with one of the very earliest inhabitants of Britain: 'We claim for him an antiquity beyond any existing parchments ... this pre-historical, aboriginal Britain' (Cust 1864: 199). Yet this argument did not sit well with his rival, Henry Ecroyd Smith (1865: 212), who rejected the antiquity of these remains, preferring the explanation that they were from a 'sea-drowned person ... buried at most within three hundred years'.

Ecroyd Smith was not the only dissenter. In an anonymous pamphlet published in 1867, the bog body itself 'spoke'. Written as an extended satirical poem, available for one shilling, Ye Leg End of Ye Prehistoric Manne (Figure 2.4) berates the diggers for disturbing his rest and castigates Cust for claiming 'My skeleton was his!' Indeed, in a fine pun that represents the first ethical discussions about the ownership and display of bog bodies in Britain, he describes himself in 'Custody' (Anon. 1867: 9). Interestingly, the front cover engraving indicates that despite the description of this as a 'skeleton' some flesh was preserved. This was not the first bog body to be given theatrical 'voice': that privilege appears to rest with Haraldskjær Woman herself, in a satirical play written by one of Worsaae's friends, Hostrup, called A Sparrow Amongst Hawks (Glob [1969] 1971: 56-7). In contrast to Leasowe Man, she is relieved to be disturbed by the journeymantailor Peter Ravn to breathe again. However, in the cod-Latin phrase cited in the preface, 'Vir Bone-Us Est Quiz', the Leasowe corpse refers to the notion of a good man becoming a source of ridicule: the skeleton is not angered merely by his exhumation but resents being labelled as prehistoric - akin to a biblical figure, 'Pheonician ... or Sistantian Chief ... / Or, p'raps, 'an Aborigine' / Who somehow 


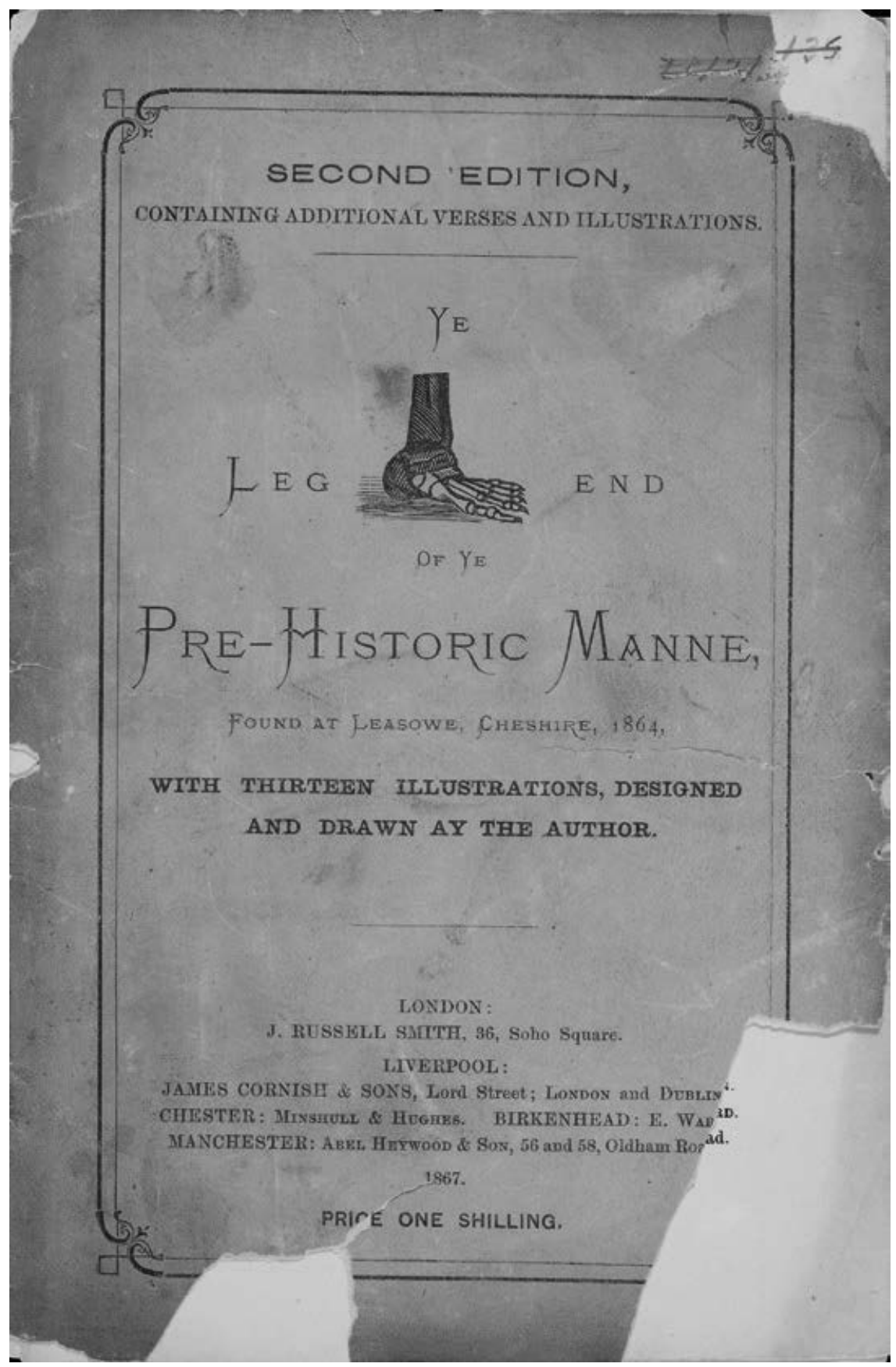

2.4 Front cover of Ye Leg End of Ye Prehistoric Manne, 1867. All rights reserved and permission to use the figure must be obtained from the copyright holder. 
came to grief' (Anon. 1867: 5). He goes on: 'They said perchance my blood had run / In some outlandish race!' confiding that his true 'calling, kith and kin' was that of a brandy-soaked sailor from Bangor, washed overboard in a gale from a coaland-slate vessel (Anon. 1867: 5, original emphasis). The poem ends with the assertion that 'I'm not a Pre-Historic Manne!' and in this the poet was right, but both he and Ecroyd Smith would have been dismayed by the radiocarbon date from the skull (now in the Natural History Museum) revealing the body to be Roman (dated to AD 95-385, Gonzalez and Schulting 2007: 350) and thus still the earliest human remains from Merseyside (Griffiths et al. 2007). The actual author of this poem and pamphlet was probably the amateur local historian, James Stonehouse (Ecroyd Smith 1873: 151). The preface makes clear his personal distaste not merely that 'Learned Bodies ... snarled over [the remains] in a dog-matic way' but 'The Skeleton [was] feeling annoyed at the idea of being charged with living in times so remote' (Anon. 1867: 2). For Stonehouse, whose main publications focused on the marvels of early to mid-nineteenth-century civic organisation and technological infrastructure (housing, road networks, railways), the notion that this Merseyside man might have been an ancient primitive, analogous to contemporary 'aborigines', was not just distasteful but unthinkable.

In another line of the poem, the skeleton seems to extoll the views of Ecroyd Smith in arguing, 'They this conclusion drew / That I must be a modern man / And therefore some one knew' (Anon. 1867: 8). This latter couplet reveals the other habit we see emerging in this period, of local populations naming the bog dead as someone they knew - usually a local colourful figure who had mysteriously disappeared. For example, in June 1853, notes made by a Mr Samuel Finney dating to 1785 were published in the Cheshire and Lancashire Historical Collector recording that:

A very extraordinary discovery was made a few years ago, by some people getting Sand in the Sand holes in Morley Gorses, where at about two feet under the surface was found the skeleton of a Man. This was supposed to be the Remains of one Richard Hamman, of Ringway, who having occasion to go to Wilmslow, about eighty years before this discovery, was seen in the Dungefold upon his return homewards, but never head of after till these Bones were discovered ... in which conjectures have been made that Hamman was murdered, stript, and buried here. (Finney cited in Worthington Barlow 1853: 45-6)

Morley Gorses lies only a few fields to the east of Lindow Common and its 'Black Lake', which is itself adjacent to Lindow Moss: the site of at least three bog body discoveries in the 1980s (Stead et al. 1986). The description seems to indicate a skeletonised body buried in the heath close by the mosses - since bone would normally be damaged by the acidic sands, such survival supports the notion this was a quite recent interment. Sand was used by peat cutters to stop the desiccated turf from blowing away in the wind (John Morgan pers. comm.) but everything depends upon the micro-environment of these remains. Since the remains were given Christian burial back in the late 1700s, we can speculate no further 
as to whether this was a prehistoric or more recent body but we can probe why local communities wanted to name and identify the dead who reappeared from these bogs.

The classic example of this is Red Christian. Grauballe Man (who will be discussed in fuller detail in Chapters 5 and 6) was recovered and studied extensively by P. V. Glob - arguably the father of bog body studies (Asingh 2009). On 26 April 1952, in Nebelgård Fen, Denmark, peat cutters reported the discovery of a body from the bog to a local doctor and antiquarian, Dr Balslev. The next day (a Sunday), Glob - then the curator of the Museum at Aarhus - was out on the bog, joining a throng of interested locals. Glob's talent in galvanising public opinion is clear: after he had brought Grauballe Man to the museum, two thousand visitors queued to see him over the following week before scientific research commenced (Glob [1969] 1971: 46). In so doing, he arguably transformed the perception not just of this well-preserved phenomenon but of the display of human remains in Denmark and further afield. Yet soon concerns were raised that this was not a prehistoric bog body at all, but the remains of a local drunkard, Red Christian, thought to have drowned in this small bog (measuring only sixty yards across) around the year 1887. An elderly farmer's wife, who had known him from childhood, swore to the likeness of the body with the consumption-ridden labourer, who had gone missing after a poaching trip that had ended in a long session at an inn at Svostrup (Glob [1969] 1971: 47). Glob's own account of the 'Red Christian' tale is frank, publishing part of a satirical poem written against him, published in a local paper that lampooned the 'scientists':

And now the folk who know what's what

Want to speak out and tell what they know.

... Glob must admit it's so. (Cited in Glob [1969] 1971: 48)

It was only the publication of the radiocarbon date that silenced these local voices, and yet they are worth listening to a little longer. This need to 'name the dead' and explain the sudden appearance of a corpse surely speaks of a continued concern to deal respectfully and appropriately with these remains. It is telling that both of these 'locally' named figures went missing within the living memory of the witnesses; their disappearance must have been disruptive, mysterious, concerning the stuff of childhood nightmares. Folklore also played its part. In the Moss of Evie, Scotland, another bog body (this time definitely historic in date and wrapped in petticoats) was tentatively identified as Mary Linklater, supposedly murdered in 1600 by a pair of 'local witches', or else interpreted as a 'poor friendless creature' from the famines of the 1730s-1740s (cited in Cowie et al. 2011: 21, cat. no. 7). Meanwhile in 1978, the burial place of Johann Spieker - a 'hawker' (or itinerant merchant) who was known to have died suddenly while crossing Goldenstadr Moor in 1828 - was finally identified. He was exhumed for formal Christian burial but his short green coat with colourful buttons, a sample of hair and the coins from its pocket were kept as museum curiosities, allowing the recent confirmation of his identity through radiocarbon dating (van der Plicht et al. 2004: 478). The Große 
Moor men (also prehistoric) were assumed to be executed members of the SS (van der Sanden 1996: 102). Even recently, the discovery of 'Moora', a bog body from Uchter Moor in 2000 (and a further hand in 2005) led to hopes she might be Elke Kerl: a girl who had gone missing in 1969 after attending a dance hall (Bauerochse et al. 2018). We can thus appreciate this deep, local desire to explain and name - to demystify a corpse and lay it to rest - as a continuity of efficacious folk beliefs discussed earlier in the chapter.

While some of these strategies were disrupted and eclipsed by scientific enquiry, local knowledge could keep the remains out of professional hands, especially in the case of bodies that needed to remain hidden. Human remains from Rørbæk, Denmark in 1893 were attributed to the handiwork of a 'known' local murderer, Ni-Kristian, and swiftly reburied in the bog (van der Sanden 1996: 42). As van der Sanden (1996: 42) notes: 'As everybody was afraid of him, no one dared report the find'. Yet seventy years later, the coffin used to give a 'decent' reinterment to the victim was accidentally exhumed, dredged up by the plough as this recently drained land was brought into cultivation. The successive acts of revelation and reburial had taken their toll: little was now left of the original body but a few bones, hair and part of a leather cap, probably indicting a prehistoric date (van der Sanden 1996). In 1920, a body exhumed at Hogenseth in Lower Saxony was left uncovered, awaiting the arrival of experts. Whomever he was thought to be (or feared to become?) the townsfolk apparently destroyed the corpse overnight (Hayen 1979). Meanwhile at Garrynahine, on Lewis, the 'red-haired' bog body found in 1878 was 'held locally to be a tacksman who was murdered by a group of local people for molesting women' (Cowie et al. 2011: 25, cat. no. 15): an example of 'rough justice' executed at a parochial level, which we will return to in Chapter 6.

In the mid to later nineteenth century then, discoveries of bog bodies were made to speak to new concerns. They might be national in ambition, looking for royalty in the face of the bog 'queen', or they might be intensely parochial, seeking to lay to rest the ghosts of the past (as with Hamman, Red Christian and $\mathrm{Ni}$-Kristian's victim) or validate the fate of perpetrators themselves. The 'run-away' lovers from Hope provide an example of why such stories should not be lightly dismissed, but some of the above examples were probably prehistoric, conveniently reinterpreted according to a local need to 'bury' the past. Yet this era was at least generally respectful of these dead ... queens, lovers, drunkards, murder and mugging victims, as well as criminals: all deserved to be noted or brought to mind at least, to set everyone's concerns to rest, before being reburied. The next era of bog body manipulation, however, was altogether darker in tone.

\section{Dark harvests}

During the late nineteenth and early twentieth centuries, Germany had taken the lead in bog body studies, both in terms of volumes of finds but also the level of 
recording and depth of scientific enquiry used to investigate the remains (van der Sanden 1996: 49). Like Lady Moira, one of the most important figures in this era was a woman: the self-educated Johanna Mestorf, who published the first 'survey' of bog bodies from Ireland, Denmark and Germany in 1871 (van der Sanden 1996: 49). In time, she would become both professor and museum director, with a particular interest in the textiles and clothing found in the bogs. It was she who coined the term 'Moorleiche' (bog body) to describe this distinct category of human remains. Mestorf used the fabric and weave of their clothing to make links with formal burials, arguing that this was a distinct German phenomenon dating to $c$. AD 200-400. Although she had initially divided her analysis into 'drowned, murdered and executed' examples, by 1907, she had narrowed her interpretation (Ravn 2010: 108), drawing on the work of Ahrends. In 1824 he was the first scholar to make a direct connection between the bog bodies and the work of Tacitus, citing: 'ignavos et imbelles et corpore infames caeno ac plaude, iniecta insupe crate, mergunt' ('the coward, the unwarlike and the man stained with abominable vices are drowned in bogs and swamps and are covered with hurdles' (Tacitus, Germany and Its Tribes XII, cited in Church and Brodribb 1942: n.p.). Mestorf thus argued that 'the bodies were those of members of German communities who had been published for some offence' (cited in van der Sanden 1996: 51). Her ideas found resonance with scholars in the Netherlands, as well as the later German archaeologist, Hahne, who reiterated the notion that bog bodies represented a 'culturally and chronologically distinct group' characteristic of 'certain German legal practices [that] led to the burial of human beings in bogs and swamps' (cited in van der Sanden 1996: 52).

It was their work that laid the foundation for the studies of Alfred Dieck, once seen as a 'grandmaster' of bog body studies for the depth of archival research he conducted, which by 1965 had risen from Hahne's 1918 catalogue (from north-west Germany, the Netherlands, Denmark and Ireland) of 56 bog bodies to 712, and by 1985 to a total of 1,859 examples (Ravn 2010: 109). Dieck made many important contributions to scholarship on the topic: he argued strongly that bog bodies dated from the Mesolithic to the Second World War itself, refuting the notion that this was a chronologically restricted phenomenon. In this analysis he was undoubtedly right, but unfortunately, many of his 'paper' examples have since been called into question (van der Sanden 2006). His original manuscript dating to 1939 was destroyed in the Allied bombing of Leipzig, and although his archive was accessioned by the Institute für Denkmalpflege in Hanover, his primary informants are now deceased and many of the records that he cites have been lost, damaged or cannot now be located. Recent scholars, particularly van der Sanden (1996: chaps 4 and 5) have criticised the way in which mere mentions of possible finds were counted as definite examples in order to elevate his total bog body count. He was uncritical with his sources, never questioning odd cross-period conflations of weapons and clothing, and he recorded extraordinary objects found with bog bodies that are now mysteriously lost (van der Sanden 1996: 65). Seminally, he never examined any human remains himself yet reported in detail on fantastical tattoos or 
discoveries of 'wreaths of flowers' placed over the dead. Some of his more erotic comments now appear both distasteful and impossible to verify (e.g. reports of young women whose hymens were apparently intact, perhaps noted as a comment upon their 'virginal' status). As van der Sanden (1996: 54) puts it, there was in many of his reports 'a grain of truth' shrouded in 'cloak of fantasy'.

Dieck's career also cast a shadow over this work. During the Second World War, when other Iron Age scholars such as the Celtic art specialist Paul Jacobstahl were forced to flee Germany, losing their archives in the process (see Crawford and Ulmschneider 2020), Dieck kept his position. During this time archaeology was increasingly deployed by Himmler (through the SS-Ahnenerbe) and the Nazi archaeologist Kossina to prove the direct descent of the German people from a pure Aryan race. The new culture history approach to archaeology and material culture allowed Kossina to chart both the supposed ethnic superiority of the ancient Germanic race and to map the original extent of their ancestral homelands' (to which the Third Reich thus argued it might now legitimately lay claim, see Trigger 2006; Lund 2002). In this manipulation of the archaeological evidence and classical texts, Tacitus's phrase corpore infames was reinterpreted by Professor and SS-Untersturmführer Karl-August Eckhardt to mean 'homosexual' (Lund 1995: 61). Ravn (2010) reveals how the very public dissemination of this idea, through the weekly SS magazine, Das Schwarze Korps, gave an authenticity and ancestral legitimacy to homophobia, resulting in Adolf Hitler's 1941 declaration of the death penalty for any homosexual within the Waffen-SS or police force and interment in a concentration camp for civilians convicted of this crime. Sanders (2009: 63) argues that this notion of the 'degenerate body' was all too easily elided with qualities of the bog itself: a kind of psychogeography of the 'soft', 'feminine', 'uncanny' and 'abnormal' - such remains became the dead testimony of 'what the race had to be cleared and cleaned of'. Yet this phrase - corpore infames - can be interpreted in many different ways: the 'stained' man, those 'marked with abominable vices', the 'disreputable' body or Glob's ([1969] 1971: 114) own 'notorious evillivers' all give very different nuances to the term, the original intent of which in Tacitus's text seems to be to draw a distinction between crimes that required public display and execution and those that should remain 'hidden'. It suited German politics of the day to legitimate what was in fact contemporary prejudice through supposedly attested ancient practice.

Quietly, though notably, Dieck disagreed. In the two hundred articles he published on the phenomena, he repeatedly cited the range of different evidence and dates to try and disrupt such a simplistic narrative (Ravn 2010: 109). This cannot have gone down well and despite Dieck's membership of the Nazi Party, the dispute marred his prospects. He was then injured during the war and taken captive by the Americans, before falling foul of post-war attitudes towards Nazi academics, and he was prevented from working formally in archaeology again. Both Eisenbeiss (1994) and van der Sanden's (1996: 62) research reveals the 'slippery ground' that Dieck trod in this post-academic limbo: a netherworld where folklore or even place-name evidence was enough to create a 'new' record. The sheer volume of his 
apparent finds earned him plaudits, renown and even awards despite his by then amateur status (van der Sanden 1996). By 2006, van der Sanden and Eisenbeiss (2006: 120) concluded that Dieck had largely fabricated much of his 'phantom population' of bog bodies, which by this time was a well-regarded topic in wider northern European scholarship. Dieck's motives can only be guessed at - perhaps this semi-fictional population was a riposte to both the Nazi ideology that sought to 'purify' Germanic prehistory as well as revenge upon an academic community that officially excluded him from research. What it does reveal though is the unstable ground of the early to mid-twentieth century and the way bog body discoveries (real or not) became 'ventriloquists' or 'mediums' (Sanders 2009: 61) for contemporary prejudice, anxiety, resistance and revenge.

\section{'Big Science' and the forensic turn}

In the last section of this chapter, I want to discuss the major trope that still dominates bog body studies: the lasting impact of the post-1950s 'Big Science' paradigm of scientific archaeology and the way this has morphed into the forensic approach. Archaeology as a discipline was revolutionised in the 1950s-1980s, through the new scientific techniques available for analysing both human remains and material culture (Trigger 2006). The most germane advances for bog body study included radiocarbon dating and its calibration, archaeobotanical and faunal analysis (of the surrounding peat, pollen and stomach contents), the microscopic analysis of textile and skin products from clothing, wood species identification and the palaeoenvironmental analysis of the bog itself (see Chapter 4). In terms of the human remains, X-radiographs were drawn from medical research into bioarchaeology, to reveal dental histories, fractures and bone preservation, while microscopic examination of well-preserved tissue enabled disease histories and histology as well as evidence for violence and trauma to be investigated. All of these techniques were deployed in the study of both Tollund and Grauballe Man, in what Glob ([1969] 1971) explicitly termed a 'post-mortem investigation'. Glob may have ended his famous account with rich, sometimes speculative forays into mythology and folklore, but the very foundation of his study was rooted in this new science and the 'evidence' it brought to light.

By the time that Ian Stead led the investigation of the Lindow Moss remains, he could draw upon the subdisciplines of microbiology, the chemical analysis of skin and potential surficial pigments, hair and nail analyses, along with charcoal, peat macrofossil, insect and parasite studies and spectroscopy on dietary remains (Stead et al. 1986). The opportunity to investigate a well-preserved corpse was conceptualised from the start as a forensic investigation, drawing upon the expertise of surgeon Jim Bourke alongside the human remains specialist, Don Brothwell. They added detailed medical approaches to the study of tissue and skeletal remains, alongside photogrammetric recording, computer tomography and facial reconstruction, in a pioneering interdisciplinary study that changed the public 
face of bog body studies in the UK (magnified through the televised QED science documentary series of 1985 - a fascinating shift from the Buried Treasure series discussed in Chapter 1). This suite of approaches continues to underpin contemporary research but with the addition of isotope, aDNA, micro-CT scanning, scanning electron microscopy (SEM) analysis of hair and fingernails, infrared reflectography, endoscopy, spectroscopy and magnetic resonance imaging, as evidenced in recent studies of Grauballe Man (Asingh and Lynnerup 2007), Tolland Man (Fischer 2012) and 'Moora' from Uchter Moor (Bauerochse et al. 2018). Advances in textile studies (e.g. Berghe et al. 2009), landscape reconstruction (e.g. Chapman 2015) and the interrogation of related deposits (such as the lipid analysis and dating of bog butter, see Downey et al. 2006), have widened the scope of scientific enquiry beyond the bodies themselves. The insights gained from this seminal new research are extensively discussed in Chapters 5 and 6, and also inform the methods adopted in Chapter 7 for Manchester's own bog head: Worsley Man. Yet what interests me here is the way that this shift in what was now scientifically possible framed bog body research in a new light.

In studies of archaeological theory dating to the height of British bog body fever (the late 1980s and early 1990s) the impact of this scientific turn was criticised by post-processual scholars. They believed the major proponents of the processual, scientific paradigm conceptualised archaeology as a mere act of discovery of the past (with the archaeologist predominantly portrayed as detective, see Shanks and Tilley 1987: 6-7), rather than a hermeneutic process of analysis and interpretation (Harris and Cipolla 2017). Writers such as Holtorf $(2007,2012)$ have criticised how this shaped a popular image of archaeology either as simple 'treasure hunting' (where the past can be simply discovered, revealed) or 'forensic examination' (where the 'facts' will emerge unproblematically from a crime scene). Most scholars of the humanities would now accept that archaeological understanding arises through a dialogue between scientific data and theoretical ideas. It is important that we remember this and pay attention to where our bog bodies come from in time, not just in terms of their origin but the moment of their discovery. As we have seen, what we decide to 'keep' from the bog, the names and voices given to the dead, whether they are seen as marvels or revenants, saints or sinners, and the histories they are made to bear witness to, all are shaped not just by archaeological methods but by the beliefs of the day and the role of the past in the present.

Today, the forensic trope has come to dominate our vision of bog body research. At one level this is understandable, grounded in a long-standing belief that many of the remains are the result of murders, often committed within living memory such as Ni-Kristian's 'victim' from Denmark or Morley Gorses Man, discussed earlier. From the 1850s onwards, while surgeons and doctors eagerly sought to acquire such remains to develop their anatomical expertise and enhance their collections, they began to find themselves clashing with criminal investigations of the dead. Thus, Ecroyd Smith (1865: 212) notes with annoyance that the archaeologists had to deal with 'the foolishly officious police officer of a neighbouring village 
[who had] ... informed the County Coroner of the suspicious discovery'. Likewise, in Kildress, Co. Tyrone, the body of a man was unearthed close to (but outside of) a churchyard in 1900, apparently dressed 'in a coachman's coat with brass buttons' with an injury to the skull that suggested it had been 'split by a blow from a turf spade' (cited in Briggs and Turner 1986: 195, no. 118). This discovery launched a murder enquiry but the suspected 'victim' named by locals was later proved to have recently died a normal death in Scotland after emigration some years earlier. It is likely the Kildress body represents the furtive interment of a suspicious death, as close to consecrated ground as possible. Yet such was the notoriety of the case that on 9 June, the neighbouring parish of Moneymore (whose rivalry with Kildress was, the newspaper reported, 'well known') reported its own 'bog head', remarkably found on the same day as Kildress, by local Moneymore man James Dowdall, on their own Ballylonghan Moss! Sergeant Bell, Dr McIver and Constable Lynch duly attended but could find nothing more than the skull. Drily, the reporter concluded that although he had certainly come to his death by 'decapitation' the police murder case had been abandoned. Wittily, he went on: 'Perhaps if as many bones as could be found as would about patch up a complete set the inquest might yet come about' (Anon. 1900: 3). While the Kildress body clearly dates to this historic era, this so far unrecorded 'paper bog head' from Moneymore sounds much more likely to be a new prehistoric example.

The detailed study of the paper bog bodies of Scotland by Cowie et al. (2011) also reveal a rich number of new post-medieval examples, many of which could be interpreted as violent or sudden deaths, from poor weather, fleeing of disputes and battles, summary executions or muggings and murders, including the case of an early eighteenth-century Arnish youth, who was killed in a quarrel with his companion on a nesting expedition. As Cowie et al. (2011) note, the murderer then fled the scene but was later caught; he confessed and was hanged for the crime, even though the victim's body took nearly three hundred years to resurface from the bog, complete with horn spoon, comb and quills. The Glenhead bog body from Wigtownshire was also assumed to be the result of a murder: a 'dark deed' as the 1852 reporter from the Dumfries and Galloway Standard put it (cited in Cowie et al. 2011:33, cat. no. 36).

The association of bogs with nefarious goings-on was not fanciful: by the nineteenth century these landscapes were physical and culturally marginalised, as the pages of the Ashton Weekly Reporter reveal. Private boxing fights run for bets, vendettas, drunk-fuelled altercations and illicit affairs often took place on Ashton and Droyslden Moss. In 1898, the corpse of a woman was found on Little Moss at the edge of Ashton. She had died from two deep wounds to the neck and throat, apparently administered by a fruit knife that was discarded nearby (Anon. 1898: 2). She was well-dressed in black kid gloves with a silver-handled umbrella and the police noted that on her finger was a 'worn' wedding ring. Many newspaper reports later, it transpired that she had probably been murdered by a chemist of her acquaintance and the two were suspected of having an affair that had soured; had she threatened to expose him, or did she arrange this secluded 
meeting to terminate their liaison? We will never know, since the guilt-ridden chemist committed suicide some weeks later, when his handwriting was matched to a note found in the victim's purse. This body on the moss reminds us eerily of some of the female remains we will encounter in Chapter 6 and it prompts us to think of rather different motivations for the killing and hiding of women in the bog than those usually deployed for Yde Girl or Huldremose Woman - not just public shame or punishment, but private humiliation, rejection or revenge.

The forensic case that overshadows all others is that of Lindow Moss and the set of remains picked out from the peat depot elevator by Andy Mould and Stephen Dooley in 1983 (Briggs and Turner 1986: 10). Initially identified as a football and hosed down in the yard, the peat workers then recognised them as the remains of a human cranium and reported the case to the police (Briggs and Turner 1986: 10). The Macclesfield force were in the process of investigating a missing-person case from twenty years prior to these events - a cold case reinvigorated by a reported confession by the husband (Peter Reyn-Bardt) to his cellmates while interred for another crime. Maria Reyn-Bardt had only been married for a couple of years before she disappeared, and as her home backed on to the moss, the police became convinced this was the missing wife. When confronted with the discovery Peter Reyn-Bardt confessed, but despite an extensive forensic search nothing other than an odd, ribbed iron pin or rod was discovered. Suspicions about the skull itself began to surface: the murderer stated he had burned and dismembered the body but no signs of this could be found on the cranium. Radiocarbon analysis was commissioned and soon revealed that the individual dated to $1740+/-80 \mathrm{BP}$, the later Roman era (Briggs and Turner 1986: 11; Joy 2009: 17); Peter Reyn-Bardt had confessed to a murder that he himself could not possibly have committed.

This scientific, clinical and forensic approach to bog bodies has been paralleled by more speculative, some would say neo-Romantic responses. The remains of Lindow Man II were rather fancifully interpreted as those of a Druid prince, 'Lovernios' (inspired in part by his fox fur armband), by Ross and Robins (1989). Neo-pagan interpretations to, and claims over, Lindow Man may have revitalised his importance (Rathouse 2016) but they have also reinvigorated debates over who can claim scholarly and cultural ownership of such 'pagan' remains (see Restell Orr and Bienkowski 2006a, 2006b; cf. Jenkins 2011, 2016). Much has been made of the 'Celtic' triple-fold death of Lindow Man (see Aldhouse-Green 2002: 89, 124) resulting in attempts to 'de-bunk' what are seen as over-interpretations of the evidence (e.g. Briggs 1995: 168-82), which will be critically discussed in Chapter 6. Even quite reasonable discussions of the violence and methods of death suffered by Lindow Man (such as Hill 2004b) have earned the ire of sceptics, keen to demystify this phenomenon (Hutton 2004b; see also response by Hill 2004a). Meanwhile in 1960s Denmark, Glob's emphasis upon ritual sacrifice to a goddess of fertility, in the cases of Tollund and Grauballe Man, have been critically situated by Asingh (2009: 18) in a similar backlash: 'In the post war years, National Romanticism was dusted off ... Just think - we Danes are descendants of a people who practised such a noble tradition as to sacrifice to the goddess of love.' These ideas continue 
to shape public interpretation but for cultural as well as methodological reasons, the forensic paradigm has come to dominate bog body studies, shaped in part by a millennial appetite for factual and fictional 'CSI'-style investigations. While Sanders's (2009) study of the cultural life of bog bodies focuses more upon texts than film and television, it is these latter media that arguably now shape the image of bog body remains (Holtorf 2007, 2012). In the UK, an episode of the fictional forensic drama Silent Witness (entitled 'Lost', 2011) began with the discovery of a supposed bog body from 'Bleaklow Moor' that was soon revealed to be a more recent murder victim. In contrast, in an episode of Endeavour (the Inspector Morse prequel) entitled 'Harvest' (2017), a body initially thought to be that of a missing local scientist turns out to be a true bog body: 'Brampton Man'. While the creative legacies of bog bodies will be further touched on in Chapter 9, it is notable that the most recent monograph by one of Britain's foremost scholars on the topic, Miranda Aldhouse-Green, draws keenly on the forensic trope, with the title of Bog Bodies Uncovered: Solving Europe's Ancient Mystery outlining an approach driven by scientific evidence, supported by a foreword by renowned crime writer, Val McDermid. We are drawn into the academic study by McDermid's promise of 'forensic techniques', how bog body studies 'peel back the layers', 'uncover' or 'expose the violence', 'examine the detail' and 'delve under the shroud' (AldhouseGreen 2016: 6-7). Yet McDiarmid warns us of the 'pieces of this puzzle' that won't fit, that can't be intuited from the evidence - the theories, the stories, the neverquite knowing - that leaves both a creative space for the crime writer as well as for the archaeologist. It is a fair warning.

Lynnerup (2015: 1010) records that the youngest 'bog body' known comes from South Zealand: the unfortunate pilot of a Second World War German aircraft that had crashed into a bog, which had subsequently been drained. Plans to turn it into a golf course relocated the wreck and the airman (complete with his wellpreserved leather flying jacket) who was exhumed and examined at the Institute for Forensic Pathology, University of Copenhagen. Though largely skeletonised due to the drying out of the peat, patches of soft tissue, especially skin, showed similar characteristics to his prehistoric counterparts (Lynnerup 2015: 1011). While this case ultimately led to the reburial of one of the war dead, the search for bodies within the bogs of Ireland has a more disturbing and disruptive meaning. In the turbulent period known as the 'Troubles', men and women in Ireland were abducted by the Provisional IRA for a variety of perceived crimes. Sixteen victims were identified by the Independent Commission for the Location of Victims' Remains (ICLVR) for intensive forensic search. Of these, thirteen have been located, initiated by sketch maps or anonymous oral testimony - tip-offs negotiated through the Peace Process in order to locate these extrajudicial executions. While coastal sand dunes, forests and lakes were used to hide such remains, bogs were particularly favoured. Most recently, in 2015, the remains of Seamus Wright and Kevin McKee were discovered, stacked in a double grave, on Coghalstown bog, Co. Meath (BBC Online News 2015). We should remember that these modern forensic investigations unfolded against the background of the most exciting era of 


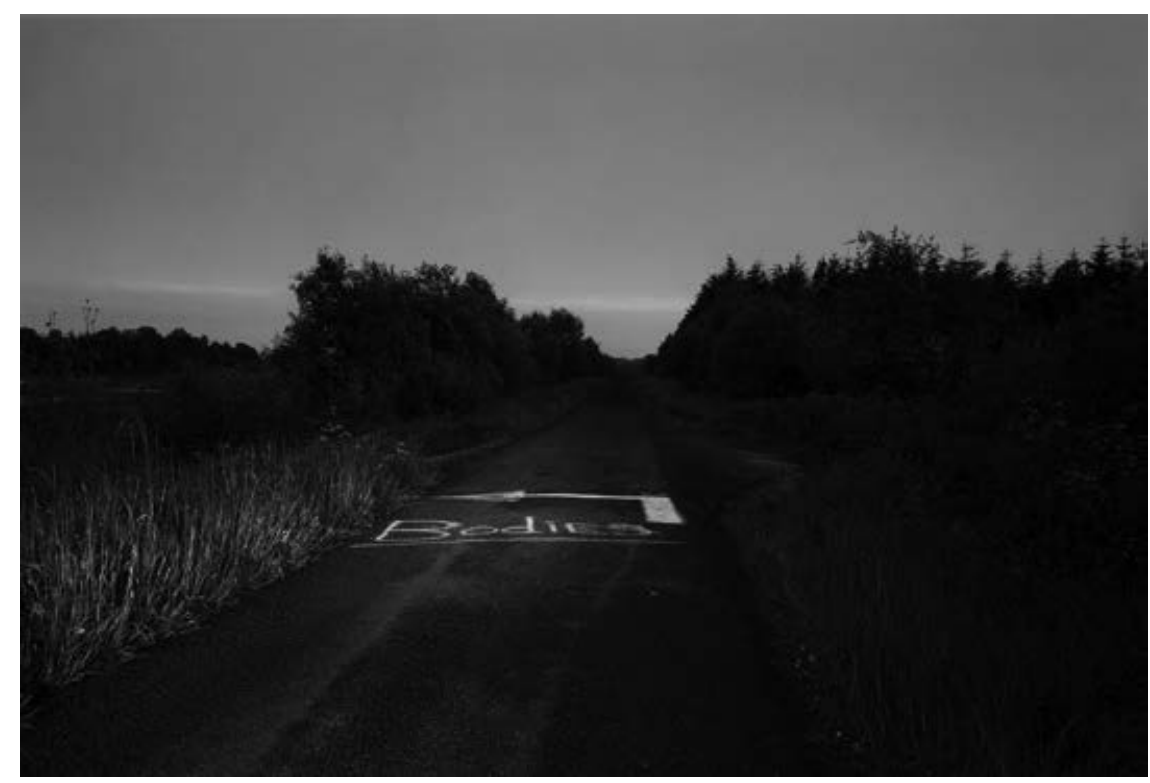

2.5 Innocent Landscapes sequence entitled 'Oristown' (graffiti), David Farrell, 2000. All rights reserved and permission to use the figure must be obtained from the copyright holder.

prehistoric and medieval bog body discoveries Ireland has ever seen (Grice 2006). Yet the murder investigations often stirred up local antipathy: early searches often led to nothing, frustrating not just the bereaved families but local communities who wanted the body found so that this era of violence might disappear again for good. A remarkable photograph by the landscape photographer David Farrell, from his collection Innocent Landscapes (2001), captures something of this resentment at apparent incompetence. In 'Oristown' (Figure 2.5), the foreground shows a narrow country track, as if lit by car headlights, winding between the fringes of mossy woodland. It is an eerie and menacing frame. Stencilled on to the road is the single word 'Bodies' with an arrow pointing directly into the bog.

\section{Conclusion}

This historiography of discovery has probed the changing reception of bog bodies: what their discovery meant, whether they were kept, reburied, defiled or curated, and how the remains were used in each era, to speak to pressing contemporary concerns. In the early historic period they were either marvels or horrors, relics or curios. There was confusion about how to deal with their remains and where they should be interred or kept. It has shown how contemporary 
eschatology - what people believed about death and the dead themselves - could be thrown into confusion by such remains, resulting in Christian and folkloric improvisation. By the nineteenth century, however, such bodies were used as part of the rethinking not just of 'deep time' but the origins of races and nations, entering institutional collections as key, if unwilling, witnesses to these pasts. Some of those narratives involve abhorrent manipulations of meaning to serve racist and homophobic ends. Yet this chapter has also shown that the claiming of the dead for scholarship vied with a more local sense of ownership or responsibility for these remains, in a struggle that continues to haunt debates over ownership and curation, particularly in the UK. Finally, it has looked at the dominance of the forensic trope in current studies, which promises us a level of insight into the lives and deaths of bog bodies beyond any antiquarian imagination. Will we, as the front cover of Aldhouse-Green (2016) seems to promise, be able to finally 'solve' the mystery? And will this put an end to what Heaney (1999) calls their 'riddling power', the 'doubling force'? I think not, for it lies, as Heaney (1999: 4) goes on to explain, in the way that 'the bodies erase the boundary-line between culture and nature, between art and life, between vision and eyesight'. What he was alluding to was the effect of a chemical and biological process that was nonetheless 'artistic' in the moment of encounter with a bog body. It was the power of being in their presence that, he argued, prompted the imagination to wonder. Thus it is to that process - of natural preservation and conservation - that the following chapter turns, as the next stage in the 'afterlife' of our bog bodies. 